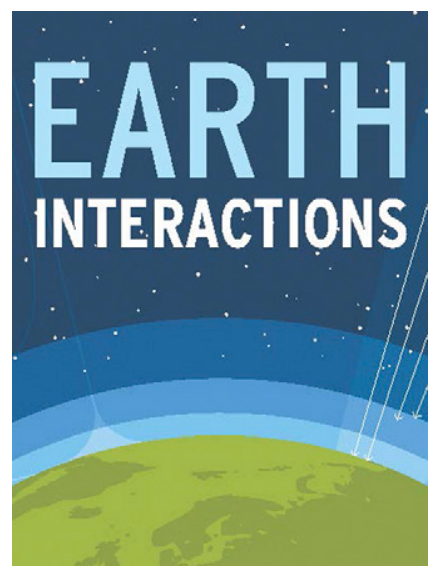

(C) 2018 American Meteorological Society. For information regarding reuse of this content and general copyright information, consult the AMS Copyright Policy (www.ametsoc.org/PUBSReuseLicenses).

\title{
A 22-Year Climatology of Cool Season Hourly Precipitation Thresholds Conducive to Shallow Landslides in Callifornia
}

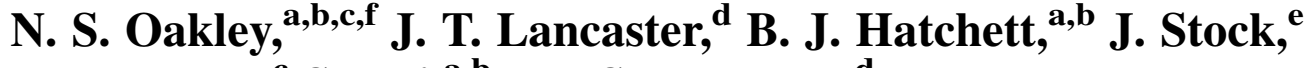 F. M. Ralph, ${ }^{c}$ S. Roj, ${ }^{\text {a,b }}$ and S. Lukashov ${ }^{d}$}

${ }^{a}$ Desert Research Institute, Reno, Nevada

${ }^{\mathrm{b}}$ Western Regional Climate Center, Reno, Nevada

${ }^{c}$ Center for Western Weather and Water Extremes (CW3E), Scripps Institution of Oceanography, La Jolla, California

${ }^{\mathrm{d}}$ California Geological Survey, Sacramento, California

${ }^{\mathrm{e}}$ U.S. Geological Survey, Menlo Park, California

Received 3 November 2017; in final form 2 May 2018

\begin{abstract}
California's winter storms produce intense rainfall capable of triggering shallow landslides, threatening lives and infrastructure. This study explores where hourly rainfall in the state meets or exceeds published values thought to trigger landslides after crossing a seasonal antecedent precipitation threshold. We answer the following questions: 1) Where in California are overthreshold events most common? 2) How are events distributed within the cool season (October-May) and interannually? 3) Are these events related to atmospheric rivers? To do this, we compile and quality control hourly precipitation data over a 22-yr period for 147 Remote Automated Weather Stations
\end{abstract}

\footnotetext{
${ }^{\mathrm{f}}$ Corresponding author: Nina S. Oakley, nina.oakley@dri.edu
} 
Earth Interactions - Volume 22 (2018) - Paper No. 14 • Page 2

(RAWS). Stations in the Transverse and Coast Ranges and portions of the northwestern Sierra Nevada have the greatest number of rainfall events exceeding thresholds. Atmospheric rivers coincide with $60 \%-90 \%$ of these events. Overthreshold events tend to occur in the climatological wettest month of the year, and they commonly occur multiple times within a storm. These statewide maps depict where to expect intense rainfalls that have historically triggered shallow landslides. They predict that some areas of California are less susceptible to storm-driven landslides solely because high-intensity rainfall is unlikely.

KEYWORDS: Cool season; Atmosphere-land interaction; Hydrometeorology; Orographic effects; Communications/decision making; Emergency preparedness

\section{Introduction}

Storm-triggered shallow landslides threaten life and property in California's steeplands. Where they mobilize into debris flows, they can result in loss of life and damage to infrastructure, homes, commercial buildings, and ecosystems (Jakob and Hungr 2005). Landslides and debris flows cause an estimated 25-50 deaths and $\$ 1-\$ 3$ billion in damages annually in the United States (NRC 2004). Impacts are anticipated to increase as continued population and economic growth increases exposure to debris-flow hazards (Santi et al. 2011).

Studies of historic events and monitoring of shallow landslides demonstrate that a range of rainfall rates can produce destabilizing increases in pore water pressure after the soil has absorbed a threshold amount of moisture from preceding rainfalls (e.g., Campbell 1975; Reid 1997; Iverson 2000; Baum et al. 2010; Stock and Bellugi 2011). The soil moisture, or volumetric water content value at which water will flow out of a soil packet (column) at the rate at which it flows in, is often called field capacity and represents a likely precondition to the triggering of widespread landsliding from intense rainfall (Campbell 1975; Wilson and Wieczorek 1995; Baum et al. 2010). Rainfall that exceeds threshold intensity values should be more likely to cause landslides (e.g., Godt et al. 2006). There are a number of historic estimates of antecedent rainfall totals and rainfall intensity-duration thresholds that will trigger shallow landslides (Campbell 1975; Caine 1980; Cannon and Ellen 1985; Wieczorek 1987; Wilson and Jayko 1997; Casadei et al. 2003; Guzzetti et al. 2008; Stock and Bellugi 2011).

A few previous studies have evaluated characteristics of subdaily precipitation in California. For example, hourly precipitation data are evaluated at a $2^{\circ} \times 2.5^{\circ}$ horizontal resolution in Lamjiri et al. (2017), and 15-min data are grouped into clusters by climate zone in Palecki et al. (2005). Brooks and Stensrud (2000) analyze hourly station data across the United States to evaluate flash flooding hazards for rainfalls exceeding $25 \mathrm{~mm} \mathrm{~h}^{-1}$, which is much higher than published landslide-triggering thresholds for California. These worthwhile studies are all either at spatial scales that are too large or thresholds that are too high or not relevant to historic landslide hazards.

Studies evaluating synoptic atmospheric conditions during mass movement events on the West Coast of the United States (Biasutti et al. 2016; Oakley et al. 2017; Young et al. 2017) find a relationship between mass movements and atmospheric rivers (ARs). ARs are narrow corridors of strong atmospheric water vapor transport that are typically associated with precipitation extremes and 
Earth Interactions - Volume 22 (2018) • Paper No. 14 • Page 3

flooding in California (e.g., Ralph et al. 2006; Ralph and Dettinger 2012). These studies improve our understanding of the synoptic meteorology of storms that trigger landslides but do not provide guidance on where and how often to expect landslide-triggering rains.

Here, we create a quality-controlled statewide rainfall intensity dataset for California from hourly gauges in the Remote Automated Weather Station (RAWS) network. These stations are often located in steeplands where landslides occur. We parse these data using published rainfall thresholds based on historic precipitation events that triggered shallow landslides. Rainfall events exceeding these thresholds are hereafter referred to as "overthreshold precipitation events" (OTPEs). We address the following questions:

- What parts of California most frequently experience OTPEs, and where are OTPEs rarely observed?

- How frequently do OTPEs occur after a specific seasonal rainfall total has been exceeded?

- How are OTPEs distributed within the cool season?

- Are OTPEs driven by atmospheric rivers?

California's soils are rarely susceptible to shallow landsliding during the dry season, when soil moisture is at its lowest. During the October-May period, when California receives most of its rain, soil moisture is replenished. This increase in initial soil moisture precedes the occurrence of free water (or positive pore water pressure) in the soil pores, widely thought to trigger instability during and shortly after storms (Wilson 1997a; Baum et al. 2010). Consequently, we analyze the wetting-up period of October-May. We analyze the period 1995-2016 to maximize the number of RAWS locations with sufficient records while incorporating several extended wet and dry periods in California's historic record. After performing quality control (QC) on the data, we calculate the number of events exceeding selected thresholds at each station. We use seasonal precipitation sums, as well as the Precipitation-Elevation Regression on Independent Slopes Model (PRISM; Daly et al. 2008), to estimate the number of OTPEs that occurred after a geomorphic province (CGS 2002) had exceeded a seasonal antecedent rainfall threshold, as those events would have the highest likelihood of triggering shallow slope failures. We use an AR catalog (Rutz et al. 2014) to assess whether OTPEs are associated with ARs.

\section{Data and methods}

\subsection{Rainfall threshold selection}

There are good reasons to expect that there is no single value of rainfall intensity and duration that will trigger storm-driven landsliding across California. A number of factors influence what rainfall intensities will create standing water in the soil column (e.g., Wilson 1997b; Larsen and Simon 1993; Baum and Godt 2010; Bogaard and Greco 2018). These include properties that affect hydraulic conductivity through time (e.g., antecedent soil moisture) and space (e.g., vegetation, geology, and topography). Once soils approach saturation, rainfall rates that exceed the rate at which the soil/bedrock interface can transmit water will likely produce 


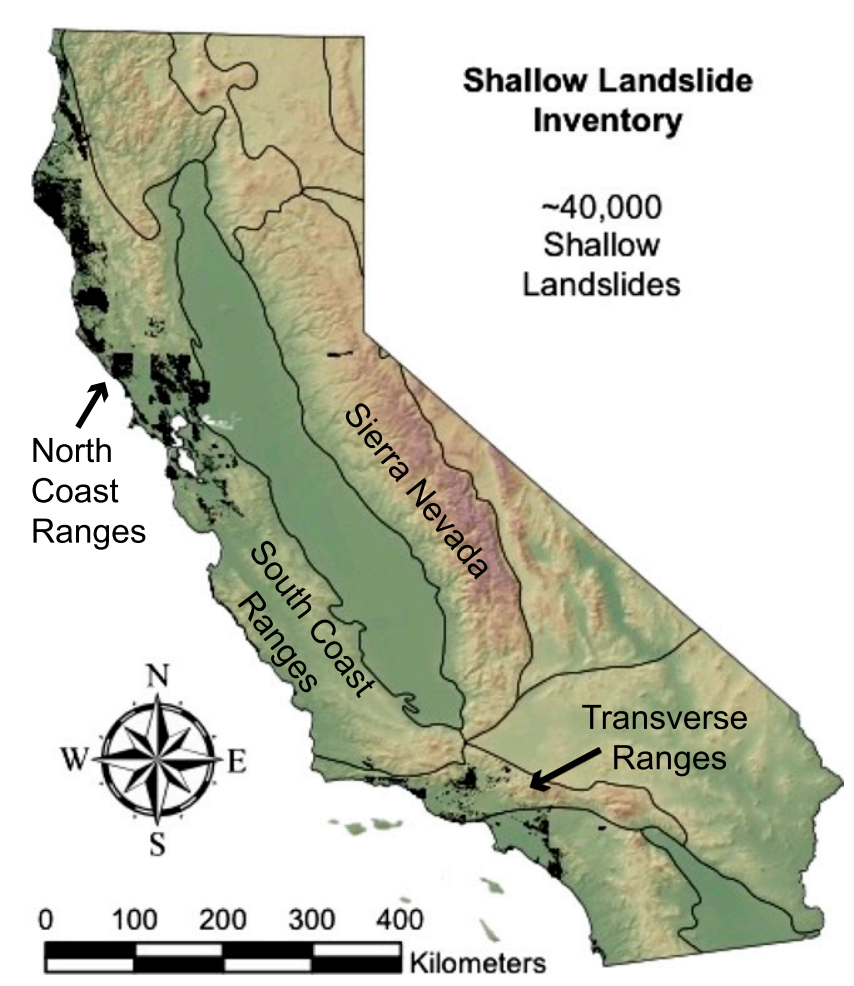

Figure 1. Map of CA landslide inventory from Wills et al. (2017) showing the general distribution of documented shallow landslides and the lack of documentation in many regions of the state. Because precipitation thresholds that trigger shallow landslides are developed from empirical data, this map serves as a general proxy for where threshold data may exist. Geomorphic provinces (CGS 2002) discussed herein are labeled.

standing water in the soil column and, hence, instability (Campbell 1975; Reid 1997).

Most rainfall thresholds in California come from historic events in the Coast Ranges or Transverse Ranges, with the bulk of the studies near critical infrastructure or population concentrations in Los Angeles and the San Francisco Bay Area. Much of California lacks historic records of storm-driven landsliding and, hence, rainfall thresholds (Figure 1; Wills et al. 2017). The applicability of broad thresholds based on climate and other factors (e.g., Caine 1980; Guzzetti et al. 2008 ) is in doubt. Consequently, we use a range of existing intensity thresholds to cover this uncertainty. These thresholds collectively represent a range of intensityduration possibilities from available studies:

1) $5 \mathrm{~mm} \mathrm{~h}^{-1}\left(T_{5}\right)$ : Approximate minimum hourly value proposed by Guzzetti et al. (2008) for triggering shallow landslides in Mediterranean climates. Cannon and Ellen (1988) observed rainfall intensities between 2.5 and $6.5 \mathrm{~mm} \mathrm{~h}^{-1}$ as triggering regional landsliding events in climatologically dry parts of the San Francisco Bay Area. 
Earth Interactions - Volume 22 (2018) • Paper No. 14 • Page 5

2) $10 \mathrm{~mm} \mathrm{~h}^{-1}\left(T_{10}\right)$ : Approximate hourly value stated by Wieczorek (1987) for triggering landslides in the Santa Cruz Mountains; adopted by Wilson (1997a) as a minimum "safety" threshold for Bay Area landslide activity and also observed in Wilson (1997a) to be associated with widespread debris-flow events in the Transverse Ranges in January-February 1993. Cannon and Ellen (1988) observed rainfall intensities between 10 and $20 \mathrm{~mm} \mathrm{~h}^{-1}$ as triggering regional landsliding events in climatologically wet parts of the San Francisco Bay Area.

3) $15 \mathrm{~mm} \mathrm{~h}^{-1}\left(T_{15}\right)$ : Approximate value stated by Caine (1980) as a broad global threshold for shallow landslide and debris-flow activity.

4) $20 \mathrm{~mm} \mathrm{~h}^{-1}\left(T_{20}\right)$ : Approximate value stated by Guzzetti et al. (2008) for triggering landslides in a "mild marine West Coast" climate; it acts as an upper limit for hourly triggering thresholds that may be suitable for regions within California's generally Mediterranean climate. Johnson and Sitar (1990) note a rate of $22.5 \mathrm{~mm} \mathrm{~h}^{-1}$ as triggering local landsliding event in Contra Costa County in February 1986.

5) $5 \mathrm{~mm} \mathrm{~h}^{-1}$ for $6 \mathrm{~h}\left(T_{6 \mathrm{~h}}\right)$ : Derived by Stock and Bellugi (2011) as a trigger for widespread shallow landslides in the Ventura area.

6) $7.5 \mathrm{~mm} \mathrm{~h}^{-1}$ for $3 \mathrm{~h}\left(T_{3 \mathrm{~h}}\right)$ : Not explicitly stated in literature reviewed, but falls among thresholds 1, 2, and 5 in terms of both intensity and duration. This threshold is indirectly supported by Campbell (1975), who concludes $6.35 \mathrm{~mm} \mathrm{~h}^{-1}$ for a period long enough to establish a perched water table was relevant for debris flows in the Santa Monica Mountains, and Wieczorek and Sarmiento (1988), who found a duration of $3 \mathrm{~h}$ was the most significant single index of the storms that caused debris flows in a portion of the San Francisco Bay Area.

\subsection{Antecedent rainfall threshold selection}

We select $250 \mathrm{~mm}$ as a minimum estimate of antecedent rainfall needed to establish soil moisture conditions conducive to shallow landslide activity in California. This value is based on several published thresholds:

- Campbell (1975): 250 mm; Santa Monica Mountains, Southern California

- Wieczorek (1987): 280 mm; La Honda, San Mateo County, Northern California

- Cannon and Ellen (1988): 254-381 mm; San Francisco Bay Area, Northern California

This static value does not account for reductions in soil moisture or pore pressures that may vary with interstorm dry periods, regional soil type, and hillslope hydrologic processes. However, its application provides a useful minimum estimate to evaluate threshold exceedance at a statewide scale.

\subsection{Data selection and quality control}

The RAWS network (Brown et al. 2011) provides hourly meteorological data for midelevation locations in complex terrain, areas where landslides are likely to 
Earth Interactions - Volume 22 (2018) - Paper No. 14 • Page 6

occur. These locations are typically not well covered by other observing networks that tend toward population centers or transportation corridors (Myrick and Horel 2008). RAWS are primarily used for fire weather monitoring and feature unheated and unshielded tipping-bucket rain gauges. Because of these characteristics, RAWS may experience undercatch (e.g., Duchon and Essenberg 2001) and do not accurately measure frozen precipitation (Daly et al. 2008). RAWS data were acquired from the Western Regional Climate Center (WRCC; https://raws.dri.edu/), and a multistep QC process was applied using the framework of Kondragunta and Shrestha (2006). A detailed explanation of data QC methods and limitations is provided in the appendix. Following QC, stations with over 80\%-complete October-May data between 1995 and 2016 and below 1700-m elevation, the approximate mean snow elevation in the Sierra Nevada (Hatchett et al. 2017), were retained. This resulted in 147 stations throughout the state (Figure 2).

At each station, the number of OTPEs associated with each of the six thresholds is counted and displayed on a map (Figures 2, 3). OTPEs are considered to be part of the same "storm event" if they occurred within $\pm 12 \mathrm{~h}$ of one another. The number of unique storm events at each station is counted and mapped, along with the ratio of storm events to total OTPEs (Figures 8, 9).

\subsection{Exceedance of $250-\mathrm{mm}$ season antecedent precipitation at stations}

At each RAWS location, hourly precipitation values are summed for each October-May season in the station's record. For each season, the date on which a sum of $250 \mathrm{~mm}$ was achieved is recorded. Any OTPEs occurring on or after this date are considered to happen after the $250-\mathrm{mm}$ threshold was attained.

Only seasons with $>70 \%$ of observations available are considered in this analysis. As the minimum $80 \%$ record completeness for a station record (section 2.2.) relates to the 1995-2016 period, some stations may have a substantial part of a particular season missing. Additionally, below $0^{\circ} \mathrm{C}$ hours were removed in the QC process, reducing available valid data points at this stage of analysis and making a relatively low threshold of $70 \%$ completeness reasonable. Only stations with $\geq 15$ seasons (132 of 147 stations) of such data are displayed on the resulting maps (Figures 5,6). Because of missing data challenges, this analysis represents a best estimate of achieving the $250-\mathrm{mm}$ threshold in each season at each station.

\subsection{Relation to atmospheric rivers}

The relation of each OTPE to AR conditions is examined by comparing the OTPE date and time to an AR catalog developed by Rutz et al. (2014). This catalog is based on a 6-hourly $2.5^{\circ}$ reanalysis product (Kalnay et al. 1996) for 1995-2015. If at least one of the two grid points closest to a station at the time closest to an OTPE observes AR conditions, the OTPE in question is considered to result from an AR event. Using two closest grid points provides a minimum estimate of OTPE relationship to AR conditions; using four closest grid points produces OTPE-AR relationships $0 \%-5 \%$ higher across each province. 
Earth Interactions - Volume 22 (2018) - Paper No. 14 • Page 7

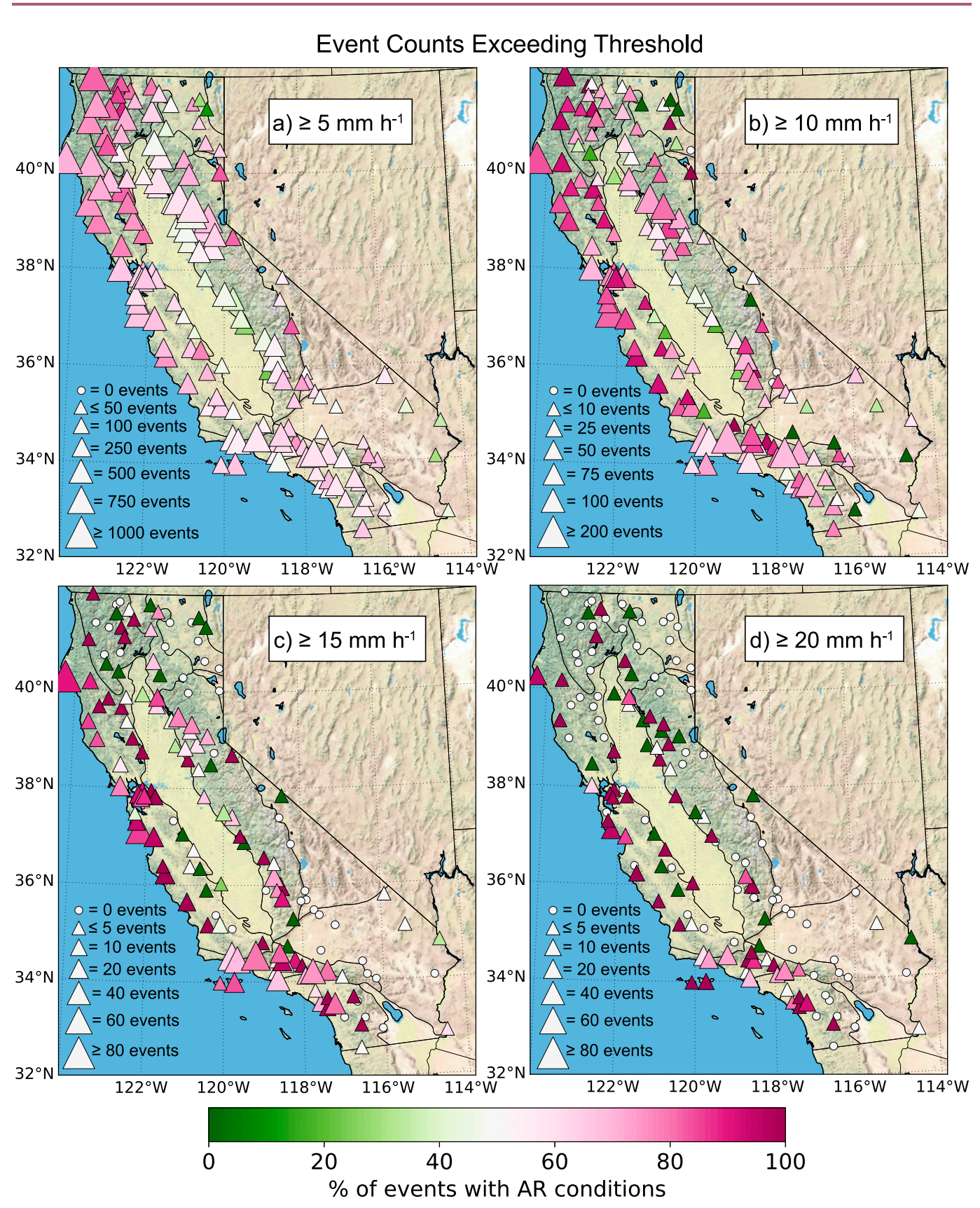

Figure 2. Marker size indicates the number of OTPEs for months of October-May spanning the period 1995-2015. Percent of events associated with ARs are represented by marker color for (a) $T_{5}$ threshold, (b) $T_{10}$ threshold, (c) $T_{15}$ threshold, and (d) $T_{20}$ threshold. AR catalog ends in 2015; thus, 2016 could not be incorporated. 


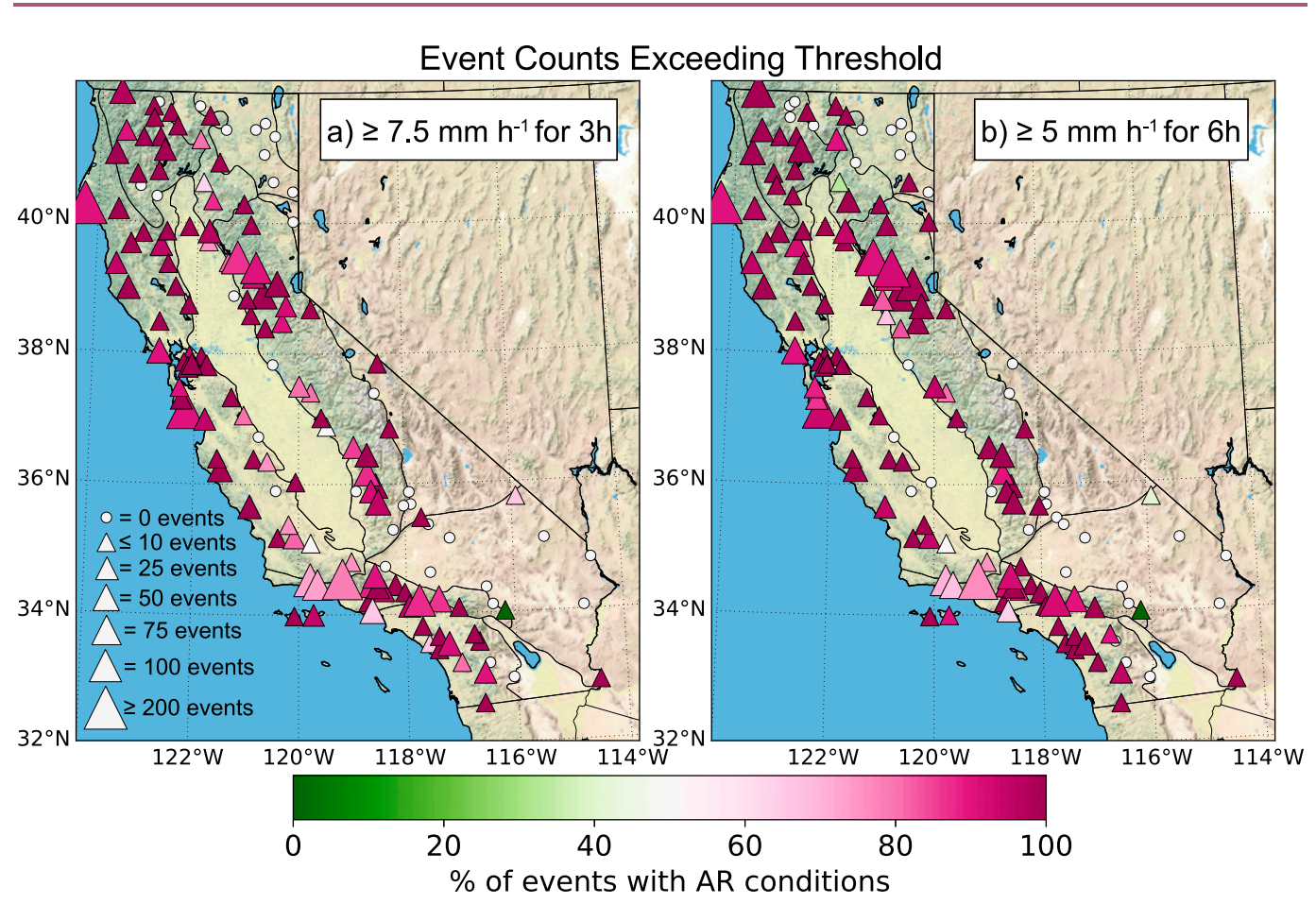

Figure 3. As in Figure 2, but for (a) $T_{3 \mathrm{~h}}$ threshold and (b) $T_{6 \mathrm{~h}}$ threshold.

\subsection{Geomorphic province-wide precipitation data (Transverse Ranges province)}

As an example of how seasonal precipitation and OTPEs vary over the period of record in a province, we examine OTPEs, monthly precipitation, date $250 \mathrm{~mm}$ is reached, and widespread landslide events for the Transverse Ranges province (Figure 12). We select this province as an example because it spans a small latitudinal gradient, has a high number of stations (16) for its areal extent compared to other provinces, and thresholds are well defined (section 2.1.).

Daily gridded 4-km PRISM precipitation estimates (Daly et al. 2008) are averaged across all grid cells in the Transverse Ranges province for each date during January 1995-December 2016 and summed into monthly totals. Provinceaveraged 30-yr (October 1981-May 2011; comprising 30 cool seasons) averages are also calculated for each month of the cool season and percent of normal values determined for each month in the study period. From the start (1 October) of each cool season, a cumulative sum of daily average precipitation is calculated, and the date of exceedance of the $250-\mathrm{mm}$ threshold is noted (pink bars in Figure 12).

Dates of several regional shallow landslide responses are shown together with OTPEs and antecedent rainfall to illustrate the relationship among these variables. Regional landslide events shown (red diamonds in Figure 12) in the Transverse Ranges are as follows: 
Earth Interactions • Volume 22 (2018) • Paper No. 14 • Page 9

- 10 January 1995: “Numerous events” (Bedrossian 1996; Irvine 1996; Wills et al. 2017)

- 3 February 1998: “>20000 events” (Hansch et al. 1998; Morton et al. 2003; Wills et al. 2017)

- 5 March 2001: “382 events” (Stock and Bellugi 2011; Wills et al. 2017)

- 9-10 January 2005: “>2000 events” (Stock and Bellugi 2011; Wills et al. 2017)

\subsection{Coastal wind observations}

To examine the relationship between coastal OTPEs and flow direction, surface wind speed and direction derived from Advanced Scatterometer (ASCAT; Ricciardulli and Wentz 2016) are composited for four stations at representative locations in coastal terrain that experienced the greatest numbers of OTPEs during the study period. Only ASCAT passes within $3 \mathrm{~h}$ of the OTPE observation are used, and ASCAT is available for the period 2007-15. ASCAT has 12.5-km horizontal resolution and was chosen over station wind observations, as it more accurately represents the larger-scale flow and potential for orographic enhancement in the area, where individual station wind observations may be biased by local terrain.

\section{Results}

For brevity, only the four provinces of greatest interest due to known high landslide occurrence or high numbers of OTPEs are described within the manuscript: North Coast Ranges, South Coast Ranges, Transverse Ranges, and Sierra Nevada (Figure 1).

\subsection{Spatial distribution of OTPES}

Events exceeding the $T_{5}$ threshold were abundant throughout much of the state, excepting the desert areas lying east of the Sierra Nevada, Transverse, and Peninsular Ranges. Some stations experienced over 1000 such events over the period studied (Table 1, Figure 2a).

At the $T_{10}$ threshold (Figure 2b), the number of OTPEs is lower than the $T_{5}$ threshold; the province median drops from several hundred events in $T_{5}$ to 30-50 events for $T_{10}$ (Table 1). The low instance of $T_{10}$ events is consistent with analysis by Lamjiri et al. (2017), who show this threshold to be at the extreme tail of hourly precipitation distributions along the West Coast. At $T_{10}$, regions experiencing high OTPEs begin to stand out: the Transverse Ranges, Cape Mendocino, the San Francisco Bay Area, and the northern Sierra Nevada.

The number of OTPEs further drops across the state at the $T_{15}$ threshold (Figure 2c); the median event count falls substantially at this threshold to $<10$ in the Sierra Nevada and North and South Coast Ranges. The Transverse Ranges have a higher median of 16 OTPEs, nearly 3 times more than all the other provinces. This may be related to more stations situated at higher elevation in this province; mean and median elevations are higher than in the North and South Coast Ranges. The Sierra Nevada stations tend to be higher than Transverse Ranges stations (Table 1), but may have atmospheric circulation characteristics less conducive to high-intensity events. 
Earth Interactions - Volume 22 (2018) - Paper No. 14 • Page 10

Table 1. For four selected geomorphic provinces: number of stations per province (row 1); range, mean, and median elevation of stations in each province (row 2); and range, mean, and median count of OTPEs among stations in each province (rows 3-8). Information in Table 1 corresponds with Figures 2 and 3.

\begin{tabular}{|c|c|c|c|c|}
\hline All OTPEs & Sierra Nevada & North Coast Ranges & South Coast Ranges & Transverse Ranges \\
\hline No. stations & 30 & 13 & 25 & 16 \\
\hline Elevation & $\begin{array}{l}\text { Range: } 210-1677 \mathrm{~m} \\
\text { Mean: } 1039 \mathrm{~m} \\
\text { Median: } 1133 \mathrm{~m}\end{array}$ & $\begin{array}{l}\text { Range: } 175-1310 \mathrm{~m} \\
\text { Mean: } 501 \mathrm{~m} \\
\text { Median: } 378 \mathrm{~m}\end{array}$ & $\begin{array}{l}\text { Range: } 107-1524 \mathrm{~m} \\
\text { Mean: } 553 \mathrm{~m} \\
\text { Median: } 488 \mathrm{~m}\end{array}$ & $\begin{array}{l}\text { Range: } 76-1661 \mathrm{~m} \\
\text { Mean: } 753 \mathrm{~m} \\
\text { Median: } 565 \mathrm{~m}\end{array}$ \\
\hline $\begin{array}{l}5 \mathrm{~mm} \mathrm{~h}^{-1} \\
T_{5}\end{array}$ & $\begin{array}{l}\text { Range: } 35-1519 \\
\text { Mean: } 487.3 \\
\text { Median: } 425\end{array}$ & $\begin{array}{l}\text { Range: } 225-2883 \\
\text { Mean: } 741.2 \\
\text { Median: } 654\end{array}$ & $\begin{array}{l}\text { Range: } 49-1348 \\
\text { Mean: } 358.2 \\
\text { Median: } 307\end{array}$ & $\begin{array}{l}\text { Range: } 122-823 \\
\text { Mean: } 384.6 \\
\text { Median: } 326\end{array}$ \\
\hline $\begin{array}{l}10 \mathrm{~mm} \mathrm{~h}^{-1} \\
T_{10}\end{array}$ & $\begin{array}{l}\text { Range: } 0-185 \\
\text { Mean: } 43.2 \\
\text { Median: } 33\end{array}$ & $\begin{array}{l}\text { Range: } 10-615 \\
\text { Mean: } 87.6 \\
\text { Median: } 41\end{array}$ & $\begin{array}{l}\text { Range: } 6-310 \\
\text { Mean: } 55.6 \\
\text { Median: } 41\end{array}$ & $\begin{array}{l}\text { Range: } 8-198 \\
\text { Mean: } 78.9 \\
\text { Median: } 51\end{array}$ \\
\hline $\begin{array}{l}15 \mathrm{~mm} \mathrm{~h}^{-1} \\
T_{15}\end{array}$ & $\begin{array}{l}\text { Range: } 0-22 \\
\text { Mean: } 5.9 \\
\text { Median: } 4\end{array}$ & $\begin{array}{l}\text { Range: } 1-130 \\
\text { Mean: } 15.5 \\
\text { Median: } 5\end{array}$ & $\begin{array}{l}\text { Range: } 0-77 \\
\text { Mean: } 13 \\
\text { Median: } 6\end{array}$ & $\begin{array}{l}\text { Range: } 2-71 \\
\text { Mean: } 22.5 \\
\text { Median: } 16\end{array}$ \\
\hline $\begin{array}{l}20 \mathrm{~mm} \mathrm{~h}^{-1} \\
T_{20}\end{array}$ & $\begin{array}{l}\text { Range: } 0-6 \\
\text { Mean: } 1.1 \\
\text { Median: } 1\end{array}$ & $\begin{array}{l}\text { Range: } 0-21 \\
\text { Mean: } 2.6 \\
\text { Median: } 0\end{array}$ & $\begin{array}{l}\text { Range: } 0-24 \\
\text { Mean: } 3.2 \\
\text { Median: } 1\end{array}$ & $\begin{array}{l}\text { Range: } 0-26 \\
\text { Mean: } 7.4 \\
\text { Median: } 4\end{array}$ \\
\hline $\begin{array}{l}7.5 \mathrm{~mm} \mathrm{~h}^{-1} 3 \mathrm{~h} \\
T_{3 \mathrm{~h}}\end{array}$ & $\begin{array}{l}\text { Range: } 0-109 \\
\text { Mean: } 23.1 \\
\text { Median: } 8\end{array}$ & $\begin{array}{l}\text { Range: } 0-316 \\
\text { Mean: } 38.2 \\
\text { Median: } 12\end{array}$ & $\begin{array}{l}\text { Range: } 0-188 \\
\text { Mean: } 25.7 \\
\text { Median: } 8\end{array}$ & $\begin{array}{l}\text { Range: } 4-107 \\
\text { Mean: } 35.5 \\
\text { Median: } 19\end{array}$ \\
\hline $\begin{array}{l}5 \mathrm{~mm} \mathrm{~h}^{-1} 6 \mathrm{~h} \\
T_{6 \mathrm{~h}}\end{array}$ & $\begin{array}{l}\text { Range: } 0-164 \\
\text { Mean: } 32.3 \\
\text { Median: } 16\end{array}$ & $\begin{array}{l}\text { Range: } 2-385 \\
\text { Mean: } 49.5 \\
\text { Median: } 22\end{array}$ & $\begin{array}{l}\text { Range: } 0-179 \\
\text { Mean: } 22.4 \\
\text { Median: } 7\end{array}$ & $\begin{array}{l}\text { Range: } 1-97 \\
\text { Mean: } 29.1 \\
\text { Median: } 14\end{array}$ \\
\hline
\end{tabular}

Regions with high OTPE count at $T_{15}$ are similar to those observed for $T_{10}$. Achieving the $T_{20}$ threshold (Figure 2d) is rare across the state; many stations have no OTPE at this threshold. The highest count of $26 T_{20}$ OTPEs was observed in the Transverse Ranges (Table 1). Median province values range from 0 to 4 (Table 1). Regions experiencing $T_{20}$ OTPEs are similar to those observed for $T_{10}$ and $T_{15}$.

For the multihour thresholds, similar spatial patterns emerge as observed in the hourly rates. For both $T_{3 \mathrm{~h}}$ and $T_{6 \mathrm{~h}}$, the areas of greatest number of OTPEs are found in the North Coast Ranges, San Francisco Bay Area, the Transverse Ranges, and the northern Sierra Nevada (Figure 3). The range and median number of $T_{3 \mathrm{~h}}$ OTPEs are higher than those of $T_{6 \mathrm{~h}}$ OTPEs for the South Coast and Transverse Ranges provinces, while the range and median number of $T_{6 \mathrm{~h}}$ OTPEs are greater than $T_{3 \mathrm{~h}}$ for the Sierra Nevada and North Coast Ranges (Table 1). Multihour frequencies are overlapping such that a 7-h period where each hour exceeds $5 \mathrm{~mm} \mathrm{~h}^{-1}$ would count as two $T_{6 \mathrm{~h}}$ OTPEs.

The provinces experiencing the highest frequencies of OTPEs are consistent with Brabb et al. (1999) and Wills et al. (2017), who indicate the North Coast Ranges are the most landslide-prone province, with the South Coast and Transverse Ranges also having high landslide incidence and susceptibility. The Sierra Nevada has infrequent landslide occurrence (Wieczorek 2002; Wills et al. 2017) but high counts of OTPEs. This discrepancy may stem from a lack of shallow landslide observations in the sparsely populated Sierra or from a geology that requires 
Earth Interactions - Volume 22 (2018) • Paper No. 14 • Page 11

extremely high precipitation rates or is not conducive to landslide activity (Wieczorek 2002).

\subsection{Relationship with atmospheric rivers and other atmospheric features}

At the $T_{5}$ threshold, the strongest relationship with ARs is in the northwestern part of the state. Farther south, the relationship is more variable, with much of the Transverse Ranges region observing 50\%-70\% of OTPEs associated with ARs (Figure 2a). A similar pattern is observed in the $T_{10}$ threshold (Figure $2 \mathrm{~b}$ ). Though overall, AR prevalence is higher (and number of OTPEs is lower) across the state at $T_{10}$, a higher fraction of OTPEs is associated with ARs in the North and South Coast Ranges and northern Sierra Nevada than the Transverse Ranges. This pattern is consistent with previous work that has examined AR contribution to annual precipitation, where the fraction of cool season precipitation associated with ARs is much higher in the northern two-thirds of California (Rutz et al. 2014).

As the number of OTPEs dwindles in the $T_{15}$ and $T_{20}$ thresholds (Figures 2c,d), the relationship with ARs becomes more variable in space; however, AR conditions still dominate in the coastal areas and some Sierra Nevada locations. These highintensity precipitation events are associated with vigorous convection, which can occur both within an atmospheric river system and during other types of events, such as cutoff low-pressure systems, that feature instability (Abatzoglou 2016). Other features, such as convergence and high-intensity precipitation along a cold front (e.g., Neiman et al. 2004), can also produce somewhat isolated, high-intensity precipitation in the absence (or presence) of an AR and can help explain variations in counts of OTPEs across provinces and non-AR events.

For the multihour thresholds, typically $>80 \%$ of OTPEs are associated with ARs across the state. A few locations in the Transverse Ranges and the South Coast Ranges for $T_{3 \mathrm{~h}}$ are in the $60 \%-80 \%$ range. This is consistent with findings that ARs produce long-duration precipitation and high storm total rainfall along the West Coast (e.g., Ralph et al. 2006; Ralph and Dettinger 2012; Lamjiri et al. 2017).

The high percentage of OTPEs at all intensities and durations associated with ARs helps to explain the spatial distribution of OTPEs throughout California. One key feature of an AR is a low-level southerly jet (LLJ; Ralph et al. 2005, 2006), which typically spans a horizontal width of several hundred kilometers. The strength of the LLJ is positively correlated with hourly rainfall rates in coastal terrain (Neiman et al. 2002). Along south-facing coastlines, the LLJ is often oriented orthogonal to the terrain, favoring the greatest upslope wind speeds and, thus, high precipitation rates (Hecht and Cordeira 2017). This hypothesis of stations with a southerly exposure preferentially observing OTPEs is supported by composite ASCAT surface winds during $T_{10}$ events (Figure 4). Composite winds are southerly with respect to each station and its surrounding area.

The northern Sierra OTPE maximum can be explained by a known coastal terrain gap at the San Francisco Bay. Moist, low-level air associated with ARs can pass through this gap and across the Central Valley, where it is then lifted orographically by the Sierra Nevada (Rutz et al. 2015; White et al. 2015). The stations representing the central Sierra are generally lower in elevation than stations in the northern and southern regions and also blocked by the Coast Ranges, which may 

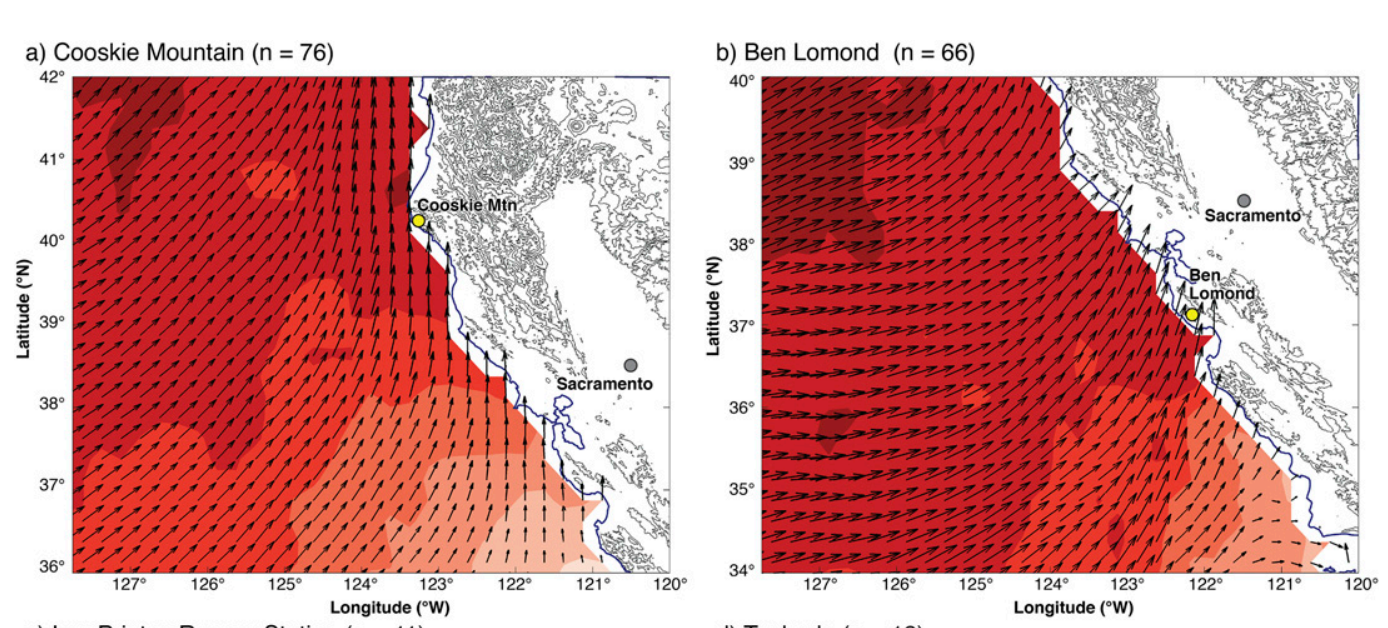

c) Los Prietos Ranger Station $(n=11)$

d) Tanbark $(n=18)$
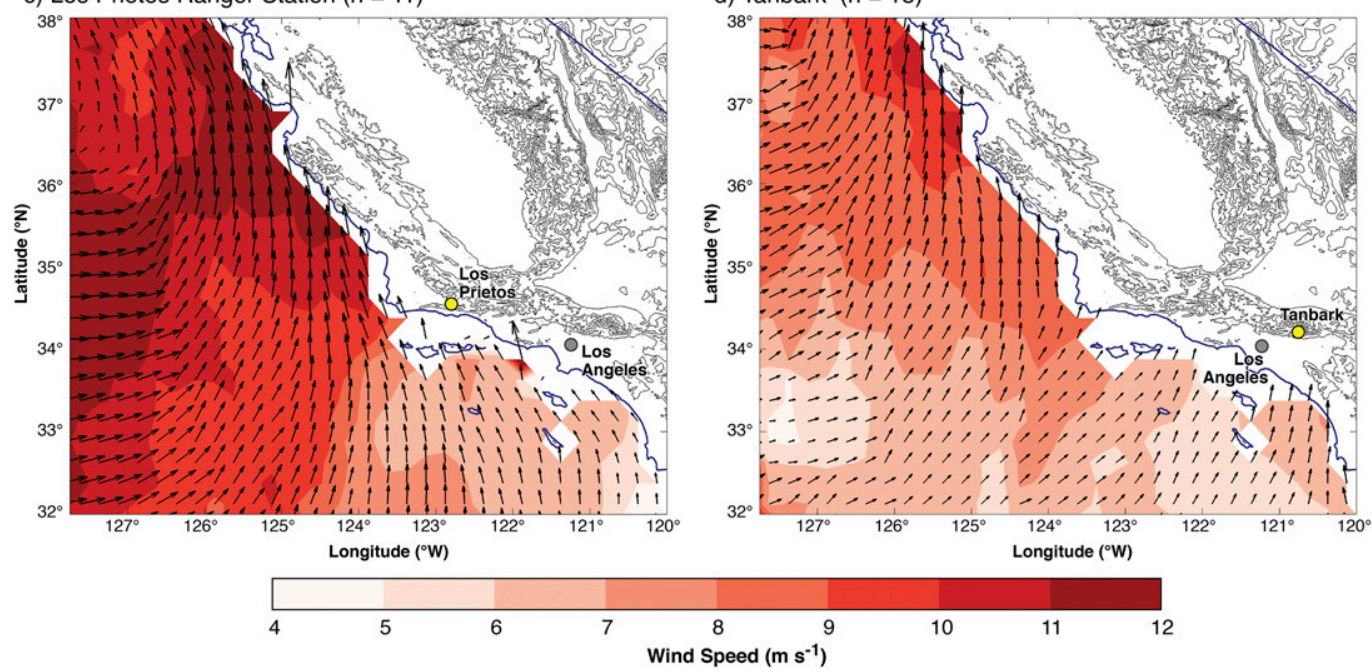

Figure 4. Composite ASCAT-derived surface wind speeds (filled contours, units in $\left.\mathrm{ms}^{-1}\right)$ and directions (shown as vectors) for $T_{10}\left(10 \mathrm{~mm} \mathrm{~h}^{-1}\right)$ precipitation events observed from 2007 to 2015 for RAWS (a) Cooskie Mountain, (b) Ben Lomond, (c) Los Prietos Ranger Station, and (d) Tanbark. The number of ASCAT observations included in each composite is noted on each map.

explain low OTPE counts in that area. The elevation of the Coast Ranges upstream of the southern Sierra is characteristically lower, which potentially allows greater moisture transport to this area in a process similar to the San Francisco Bay gap and results in slightly higher OTPE values in the southern Sierra than the central Sierra.

\subsection{OTPEs after $250-\mathrm{mm}$ antecedent seasonal precipitation threshold met}

As to be expected, the count of OTPEs occurring after the 250-mm antecedent season threshold was met decreased across all thresholds examined (Figures 5, 6, Table 2), as compared to all OTPEs (Figures 2, 3, Table 1). For the single-hour 


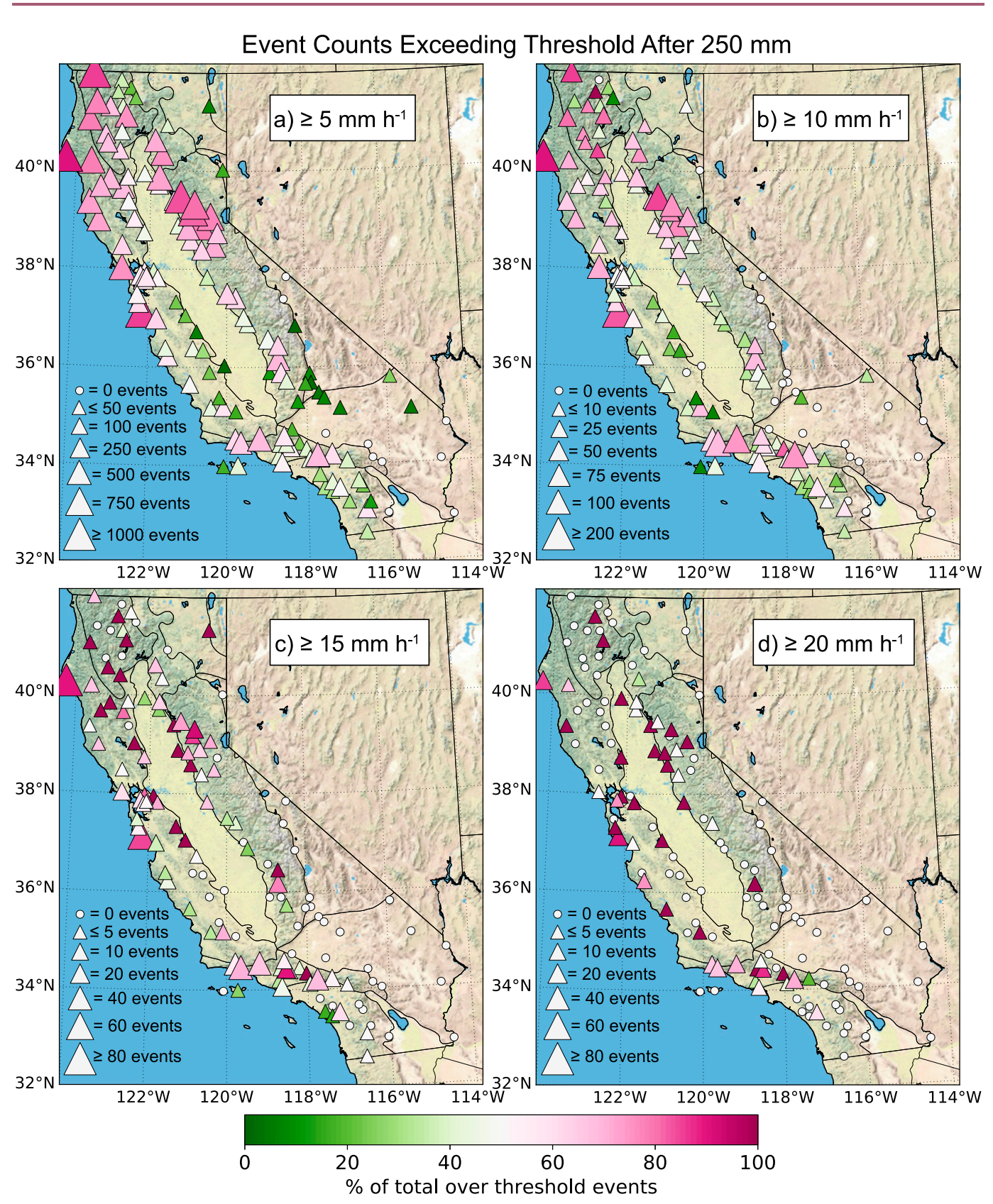

Figure 5. Marker sizes indicate the number of OTPEs occurring after the $250-\mathrm{mm}$ antecedent precipitation threshold is met, summed over each OctoberMay season 1995-2016 for (a) $T_{5}$ threshold, (b) $T_{10}$ threshold, (c) $T_{15}$ threshold, and (d) $T_{20}$ threshold. Marker colors indicate the fraction of total OTPE events at a station occurring after the $250-\mathrm{mm}$ threshold has been met. Only October-May seasons with $\geq 70 \%$ of data available are incorporated, and only stations with $\geq 15$ seasons of such data are displayed on map. 


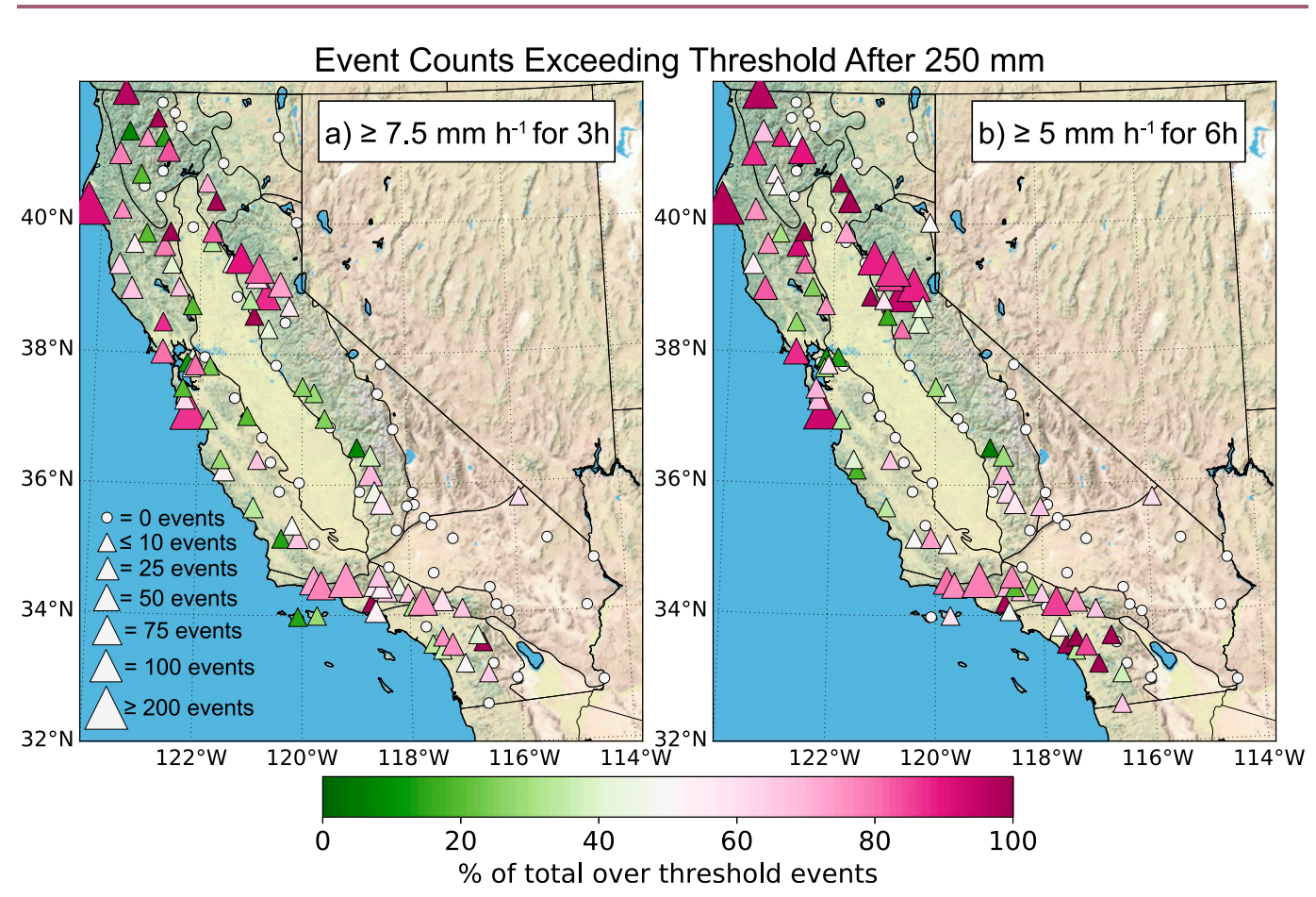

Figure 6. As in Figure 5, but for (a) $T_{3 \mathrm{~h}}$ threshold and (b) $T_{6 \mathrm{~h}}$ threshold.

thresholds $T_{5-250}, T_{10-250}$, and $T_{15-250}$, the median count of OTPEs was nearly half that observed for $T_{5}, T_{10}$, and $T_{15}$. For the multihour thresholds $T_{3 \mathrm{~h}-250}$ and $T_{6 \mathrm{~h}-250}$, there is a bit more variability in decrease from counts of all OTPEs, with reductions in median ranging from $25 \%$ to $70 \%$ fewer events after $250 \mathrm{~mm}$. These numbers are impacted by exclusion of some seasons and stations from the analysis due to lack of complete data (section 2.4.), but still provide an estimate for the change in number of OTPEs across the state after the $250-\mathrm{mm}$ season threshold has been met.

The same regions dominate in having the greatest number of OTPEs after $250 \mathrm{~mm}$ as in analysis of all OTPEs: portions of the Coast Ranges, the northern Sierra Nevada, and the Transverse Ranges. Across all thresholds, Northern California tends to have a greater fraction of total OTPEs occurring after $250 \mathrm{~mm}$ than Southern California, shown in darker magenta in Figures 5 and 6. Much of the northern part of the state observes higher mean annual precipitation totals than the southern portion. Additionally, the wettest month of the year is February for the Transverse and South Coast Ranges, whereas December and January are the wettest months for the Sierra Nevada and North Coast Ranges (Figure 10). This means the 250-mm threshold is typically reached much earlier in the year in the northern part of the state, allowing for more opportunities later in the season to have OTPEs occur after the 250-mm threshold has been met. Using the $250-\mathrm{mm}$ threshold across the state creates a bias toward more after-250-mm OTPEs in areas with higher mean annual precipitation, but as we do not know antecedent precipitation thresholds across most of the state, we apply this as a minimum estimate. 
Earth Interactions V Volume 22 (2018) • Paper No. 14 • Page 15

Table 2. For four selected geomorphic provinces: number of stations per province (row 1); range, mean, and median count of OTPEs among stations in each province after the 250-mm antecedent precipitation threshold has been met (rows 2-7); and range, mean, and median count of OTPEs for exceedance of $250-\mathrm{mm}$ antecedent precipitation threshold, $T_{6 \mathrm{~h}}$ threshold, and $T_{10}$ threshold $\left(T_{6 \mathrm{~h} 10-250}\right)$ among stations in each province (row 8). Information corresponds to Figures 5, 6, and 7a.

\begin{tabular}{|c|c|c|c|c|}
\hline After 250-mm OTPEs & Sierra Nevada & North Coast Ranges & South Coast Ranges & Transverse Ranges \\
\hline No. stations & 26 (of 30) & 13 (of 13) & 25 (of 25$)$ & 15 (of 16 ) \\
\hline $\begin{array}{l}5 \mathrm{~mm} \mathrm{~h}^{-1} \\
T_{5-250}\end{array}$ & $\begin{array}{l}\text { Range: } 1-1156 \\
\text { Mean: } 332.2 \\
\text { Median: } 255\end{array}$ & $\begin{array}{l}\text { Range: } 123-2544 \\
\text { Mean: } 531.4 \\
\text { Median: } 384\end{array}$ & $\begin{array}{l}\text { Range: } 2-1147 \\
\text { Mean: } 191.2 \\
\text { Median: } 145\end{array}$ & $\begin{array}{l}\text { Range: } 24-501 \\
\text { Mean: } 192.9 \\
\text { Median: } 150\end{array}$ \\
\hline $\begin{array}{l}10 \mathrm{~mm} \mathrm{~h}^{-1} \\
T_{10-250}\end{array}$ & $\begin{array}{l}\text { Range: } 0-141 \\
\text { Mean: } 28.4 \\
\text { Median: } 18\end{array}$ & $\begin{array}{l}\text { Range: } 4-551 \\
\text { Mean: } 67.4 \\
\text { Median: } 21\end{array}$ & $\begin{array}{l}\text { Range: } 0-255 \\
\text { Mean: } 30.1 \\
\text { Median: } 15\end{array}$ & $\begin{array}{l}\text { Range: } 2-135 \\
\text { Mean: } 44.4 \\
\text { Median: } 31\end{array}$ \\
\hline $\begin{array}{l}15 \mathrm{~mm} \mathrm{~h}^{-1} \\
T_{15-250}\end{array}$ & $\begin{array}{l}\text { Range: } 0-17 \\
\text { Mean: } 3.6 \\
\text { Median: } 2\end{array}$ & $\begin{array}{l}\text { Range: } 0-116 \\
\text { Mean: } 12.5 \\
\text { Median: } 4\end{array}$ & $\begin{array}{l}\text { Range: 0-61 } \\
\text { Mean: } 7.2 \\
\text { Median: } 2\end{array}$ & $\begin{array}{l}\text { Range: } 0-42 \\
\text { Mean: } 12.1 \\
\text { Median: } 4\end{array}$ \\
\hline $\begin{array}{l}20 \mathrm{~mm} \mathrm{~h}^{-1} \\
T_{20-250}\end{array}$ & $\begin{array}{l}\text { Range: } 0-6 \\
\text { Mean: } 0.7 \\
\text { Median: } 0\end{array}$ & $\begin{array}{l}\text { Range: } 0-18 \\
\text { Mean: } 1.9 \\
\text { Median: } 0\end{array}$ & $\begin{array}{l}\text { Range: } 0-19 \\
\text { Mean: } 2 \\
\text { Median: } 0\end{array}$ & $\begin{array}{l}\text { Range: } 0-15 \\
\text { Mean: } 4.1 \\
\text { Median: } 1\end{array}$ \\
\hline $\begin{array}{l}7.5 \mathrm{~mm} \mathrm{~h}^{-1} 3 \mathrm{~h} \\
T_{3 \mathrm{~h}-250}\end{array}$ & $\begin{array}{l}\text { Range: } 0-83 \\
\text { Mean: } 15 \\
\text { Median: } 6\end{array}$ & $\begin{array}{l}\text { Range: } 0-289 \\
\text { Mean: } 31.1 \\
\text { Median: } 7\end{array}$ & $\begin{array}{l}\text { Range: } 0-161 \\
\text { Mean: } 15.4 \\
\text { Median: } 2\end{array}$ & $\begin{array}{l}\text { Range: } 1-71 \\
\text { Mean: } 21.6 \\
\text { Median: } 12\end{array}$ \\
\hline $\begin{array}{l}5 \mathrm{~mm} \mathrm{~h}^{-1} 6 \mathrm{~h} \\
T_{6 \mathrm{~h}-250}\end{array}$ & $\begin{array}{l}\text { Range: } 0-127 \\
\text { Mean: } 24.2 \\
\text { Median: } 6\end{array}$ & $\begin{array}{l}\text { Range: } 0-371 \\
\text { Mean: } 41.1 \\
\text { Median: } 12\end{array}$ & $\begin{array}{l}\text { Range: } 0-153 \\
\text { Mean: } 14.2 \\
\text { Median: } 2\end{array}$ & $\begin{array}{l}\text { Range: } 0-75 \\
\text { Mean: } 19.3 \\
\text { Median: } 9\end{array}$ \\
\hline $\begin{array}{l}5 \mathrm{~mm} \mathrm{~h}^{-1} 6 \mathrm{~h} \text { with one } \\
10 \mathrm{~mm} \mathrm{~h}^{-1} \\
T_{6 \mathrm{~h} 10-250}\end{array}$ & $\begin{array}{l}\text { Range: } 0-86 \\
\text { Mean: } 13.8 \\
\text { Median: } 3\end{array}$ & $\begin{array}{l}\text { Range: } 0-302 \\
\text { Mean: } 30.1 \\
\text { Median: } 3\end{array}$ & $\begin{array}{l}\text { Range: } 0-121 \\
\text { Mean: } 11.3 \\
\text { Median: } 1\end{array}$ & $\begin{array}{l}\text { Range: } 0-68 \\
\text { Mean: } 16.6 \\
\text { Median: } 7\end{array}$ \\
\hline
\end{tabular}

Some of California's most devastating landslides have occurred when soils were already moist $(>250-\mathrm{mm}$ antecedent rainfall), hourly rainfalls were intense ( $T_{10}$ event), and rainfall duration was sufficiently long to generate widespread pore pressure increase ( $T_{6 \mathrm{~h}}$ event). The cases of this triple consequence (Figure 7a) are significantly fewer than for the $T_{6 \mathrm{~h}-250}$ threshold, especially in the northern part of the state. For example, Cooskie Mountain on Cape Mendocino in the North Coast Ranges observed $371 T_{6 \mathrm{~h}-250}$ events and only $302 T_{6 \mathrm{~h} 10-250}$ events. In contrast, incidences in the Transverse Ranges did not decrease as much as other regions with the addition of the $T_{10}$ requirement. Tanbark, in the central Transverse Ranges, observed $75 T_{6 \mathrm{~h}-250}$ events and $68 T_{6 \mathrm{~h} 10-250}$ events (Table 2).

\subsection{Temporal distribution of OTPEs}

OTPEs are considered to be part of the same storm event if they occur within $12 \mathrm{~h}$ of each other. At the $T_{5}$ threshold, there is generally a low ratio of storm events to OTPEs across the state, indicating it is common for several OTPEs to occur during a storm event (Figure 8a). At the more extreme $T_{10}$ threshold, the ratio 


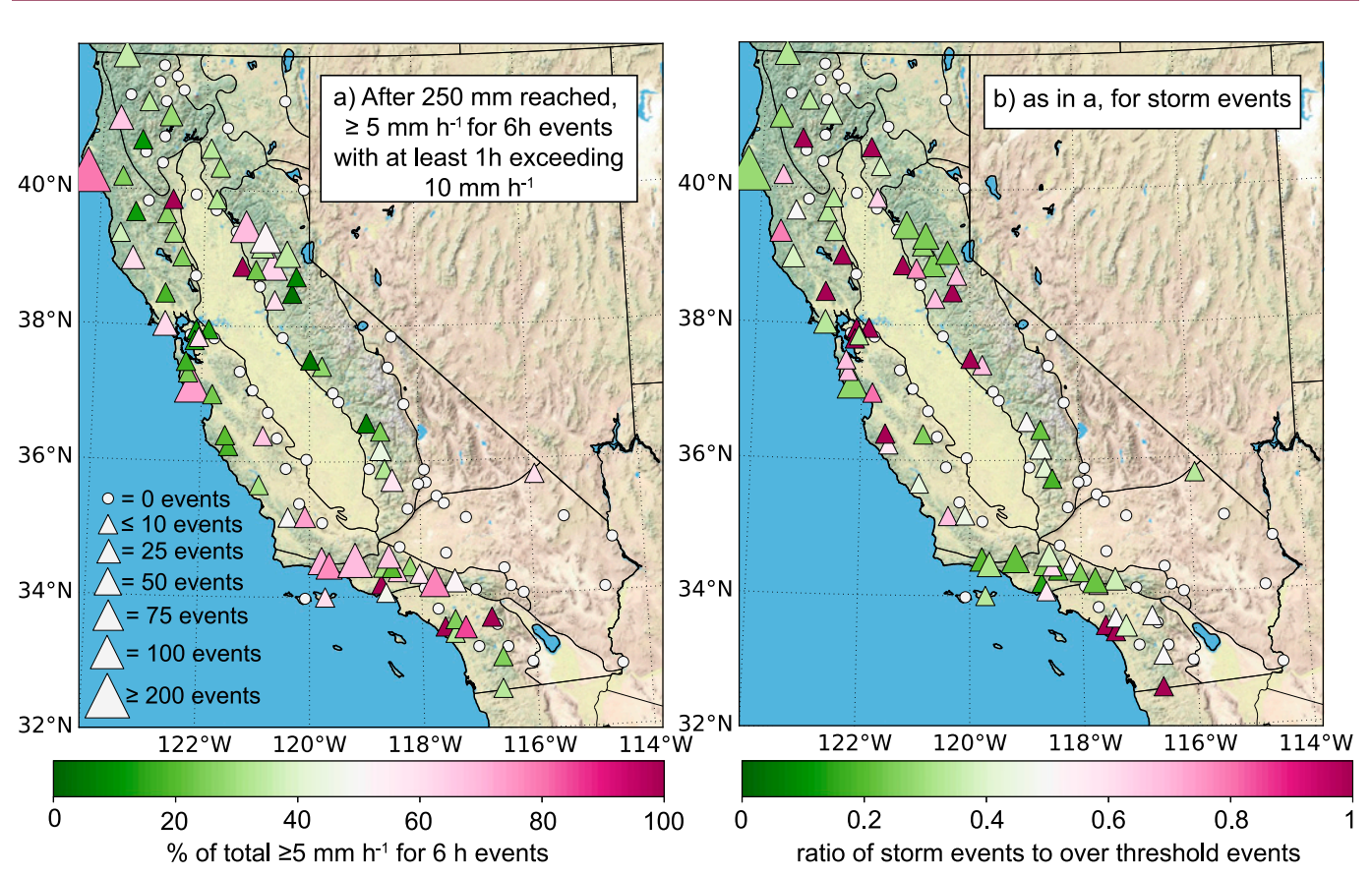

Figure 7. (a) Marker sizes indicate the number of events over the 1995-2016 period where the $250-\mathrm{mm}$ antecedent precipitation threshold has been met, a $\geq 5 \mathrm{~mm} \mathrm{~h}^{-1}$ for 6-h OTPEs has occurred, and at least one of those $6 \mathrm{~h}$ had a precipitation rate $\geq 10 \mathrm{~mm} \mathrm{~h}^{-1}$ (the $T_{6 \mathrm{~h} 10-250}$ threshold). Marker colors indicate the fraction of total $\geq 5 \mathrm{~mm} \mathrm{~h}^{-1}$ for 6 -h events at a station that meet these criteria. (b) Marker sizes indicate the number of storm events producing $T_{6 h 10-}$ 250 events, and marker color indicates the ratio of storm events to $T_{6 \mathrm{~h} 10-250}$ events. Smaller (darker green) values indicate more $T_{6 \mathrm{~h} 10-250}$ events per storm, and larger values (darker magenta) indicate fewer $T_{6 \mathrm{~h} 10-250}$ events per storm.

increases, indicating fewer OTPEs per storm (Figure 8b). At the $T_{15}$ and $T_{20}$ thresholds, for most areas of the state, there is a close to 1:1 ratio between storms and OTPEs (Figures 8c,d). The exception at these thresholds occurs in the Transverse Ranges, where there are cases of multiple OTPEs per storm, shown by the $<1.0$ ratio. A few other stations in the state observe multiple OTPEs per storm at these thresholds as well.

For the multihour thresholds $T_{3 \mathrm{~h}}$ and $T_{6 \mathrm{~h}}$, it is common to see a low ratio of storm events to OTPEs, especially in the areas of frequent OTPEs (Figure 9; Cape Mendocino and parts of the North Coast Ranges, northern Sierra Nevada, San Francisco Bay Area, and the Transverse Ranges). Across the state, the $T_{6 \mathrm{~h}}$ threshold displays slightly more OTPEs per storm than the $T_{3 \mathrm{~h}}$ threshold. For the multithreshold OTPEs, $T_{6 \mathrm{~h} 10-250}$, it is common for multiple events to occur within a storm (Figure 7b). This suggests that these OTPEs are not necessarily frequent over time, but are likely to occur multiple times in a significant storm.

Across all four provinces and all six thresholds, OTPEs were most frequent in the months of December-February (Figures 10, 11). Broadly across California, the wettest month of the year is typically December in the northern part of the state, 
Earth Interactions - Volume 22 (2018) • Paper No. 14 • Page 17

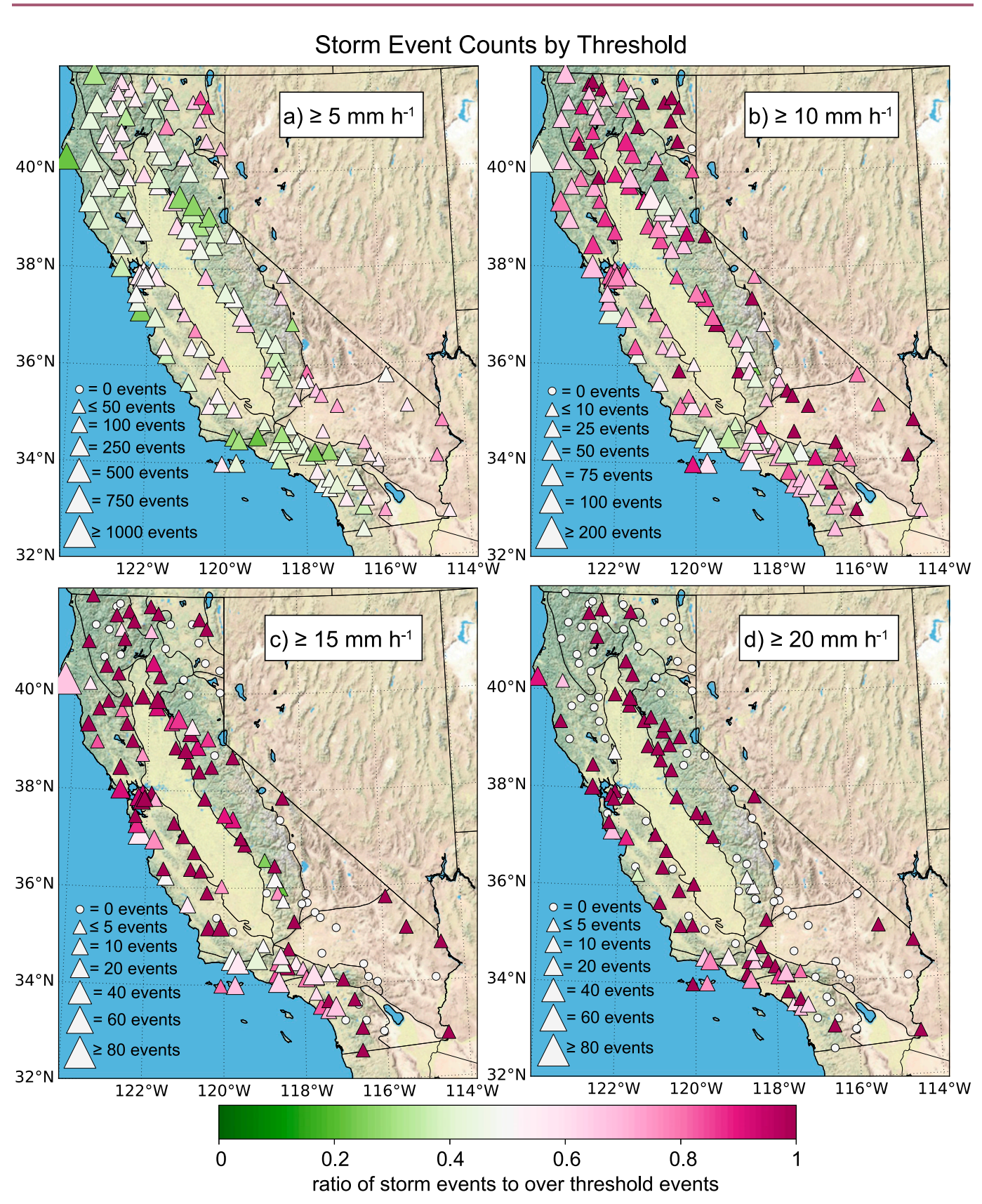

Figure 8. Marker sizes indicate the number of storm events producing OTPEs, and marker color indicates the ratio of storm events to OTPEs at each threshold. Smaller (darker green) values indicate more OTPE events per storm, and larger values (darker magenta) indicate fewer OTPEs per storm for (a) $T_{5}$ threshold, (b) $T_{10}$ threshold, (c) $T_{15}$ threshold, and (d) $T_{20}$ threshold. 


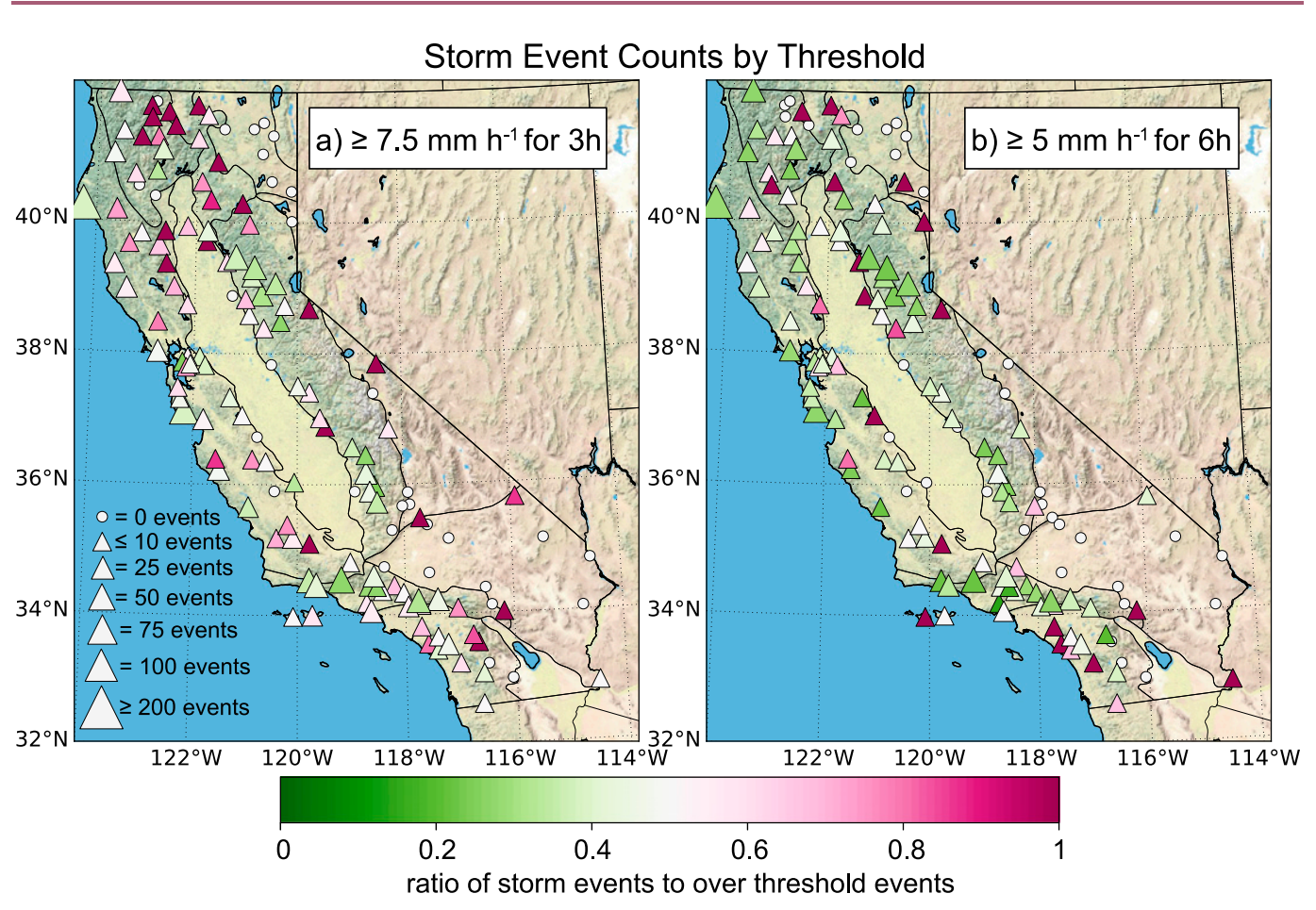

Figure 9. As in Figure 8, but for (a) $T_{3 \mathrm{~h}}$ threshold and (b) $T_{6 \mathrm{~h}}$ threshold.

January in the central portion, and February in the south, with transitional areas in between (WRCC 2017; Figure 10). The month of highest incidence of OTPEs at stations within each province generally coincides with this pattern. There is an exception in the Sierra Nevada and South Coast Ranges. These provinces span a large latitudinal range across transitional areas, producing a discrepancy between the climatological wettest month and peak month for OTPEs, though the relationship generally holds at the station level.

Figure 12 provides an example of the variability of OTPEs through time, demonstrated using the Transverse Ranges province and the $T_{10}$ threshold. The number of total OTPEs and OTPEs occurring after the 250-mm antecedent precipitation threshold is highly variable from year to year. Six years in the Transverse Ranges did not reach 250-mm threshold, based on PRISM data. OTPEs tend to occur in clusters during storm events, with multiple OTPEs across the province happening on a single day or sequence of days. Regional shallow landslide events (red diamonds in Figure 12) occur coincident with, or following, exceedance of the 250-mm threshold and multiple OTPEs in the province.

\subsection{OTPE relationship to elevation}

We use a scatterplot (Figure 13) to examine potential relationships between OTPE count and elevation. For brevity, only results of this analysis for $T_{10}$ and $T_{6 \mathrm{~h}}$ are provided. In an idealized case at a local scale, we would anticipate precipitation intensity to increase with elevation (e.g., Lin et al. 2001; Neiman et al. 2002). In the 
Earth Interactions - Volume 22 (2018) - Paper No. 14 • Page 19

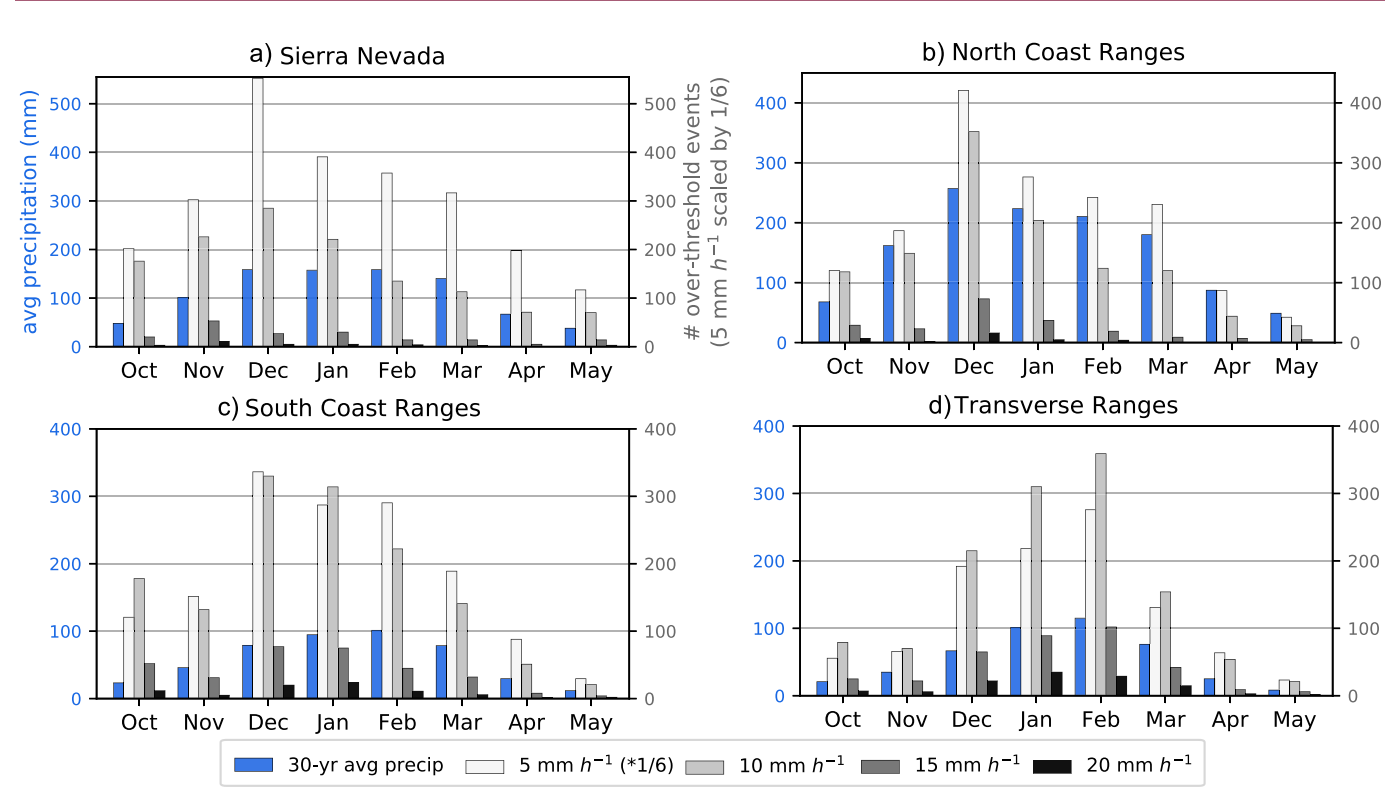

Figure 10. Histograms of $30-y r$ average precipitation derived from PRISM averaged over each province (blue bars), and monthly count of $T_{5}$ (white bars), $T_{10}$ (light gray bars), $T_{15}$ (dark gray bars), and $T_{20}$ (black bars) OTPEs by province. Because of the large number of $T_{5}$ events, they are scaled by a factor of $1 / 6$ such that they can be displayed alongside the other hourly thresholds. Plots are show for the (a) Sierra Nevada, (b) North Coast Ranges, (c) South Coast Ranges, and (d) Transverse Ranges provinces.

California-wide approach taken here, no relationship between OTPEs and elevation exists $\left(r^{2}<0.05\right.$ for all thresholds). Table 1 also illustrates the tenuous relationship between elevation and OTPEs; provinces with higher-elevation stations do not necessarily observe a greater number of OTPEs at each threshold.

There are several possible explanations for why we do not see a clear elevation-OTPE relationship. First, station siting with respect to upstream largescale terrain features plays a major role in precipitation distribution. Moisture flux convergence driven by regional topography or gaps in upstream terrain can enhance the likelihood of heavy precipitation (White et al. 2015), while higherelevation terrain upstream can reduce this likelihood by creating a rain-shadow effect (Ralph et al. 2003). We do not account for station aspect in this analysis, as aspect can be considered at many different spatial scales; evaluating the best representation of aspect with respect to precipitation for each station is beyond the scope of this study. Second, mesoscale circulations related to terrain, such as the Sierra barrier jet (Lundquist et al. 2010) or other blocking regimes (e.g., Hughes et al. 2009), can affect orographic precipitation gradients. Third, there are climatological variations in precipitation across the state that affects the number of opportunities for OTPEs to occur, and those variations are not considered in this bulk analysis. Regional evaluations would yield a much smaller station sample size and still do not provide the elevation transect information needed to adequately address this issue. 
Earth Interactions - Volume 22 (2018) • Paper No. 14 • Page 20

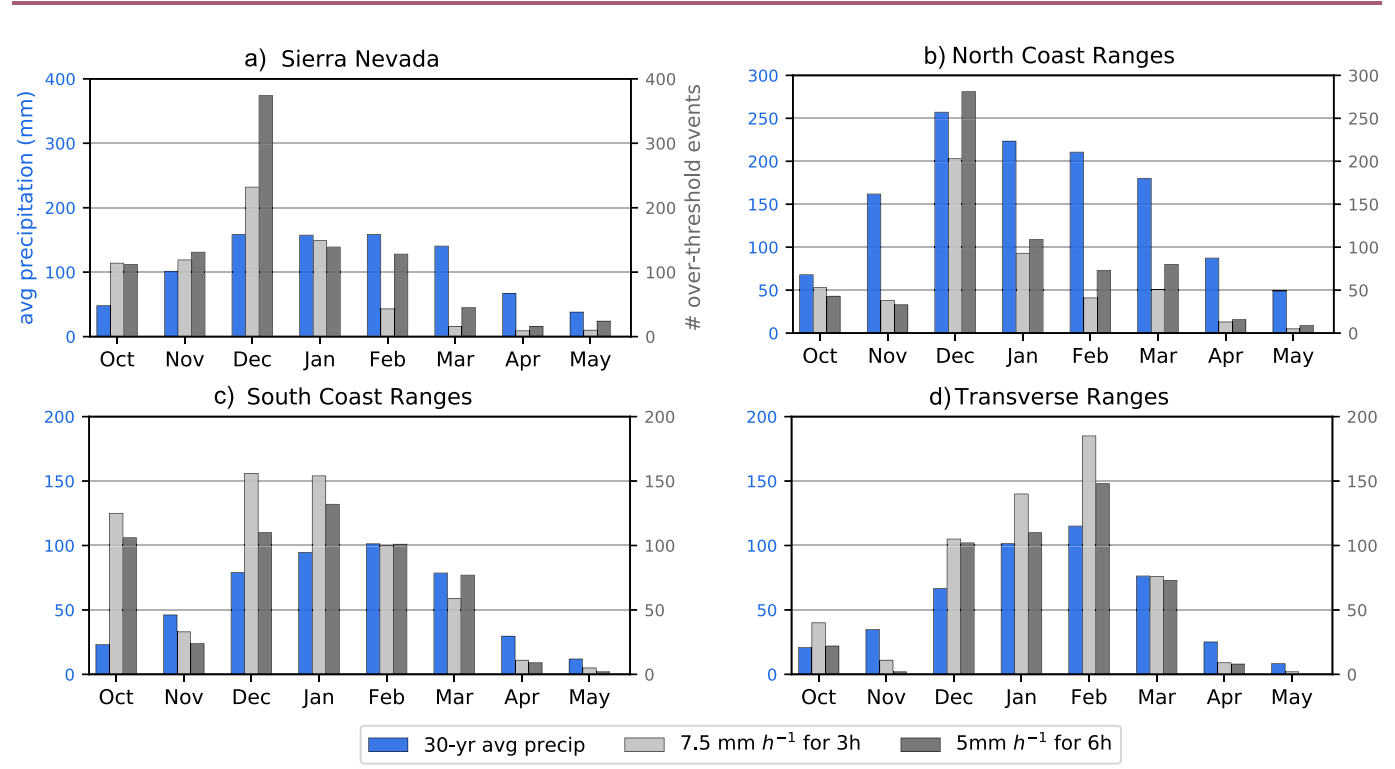

Figure 11. Histograms of $30-y r$ average precipitation derived from PRISM averaged over each province (blue bars), and monthly count of $T_{3 \mathrm{~h}}$ (light gray bars) and $T_{6 h}$ (dark gray bars) OTPEs by province. Plots are show for the (a) Sierra Nevada, (b) North Coast Ranges, (c) South Coast Ranges, and (d) Transverse Ranges provinces.

\section{Discussion}

Exceedance of antecedent moisture and existing precipitation intensityduration thresholds has long been the standard for forecasting which rainfall intensities will trigger shallow landslides (e.g., Caine 1980; Guzzetti et al. 2008). Previous work has evaluated variability of subdaily precipitation intensities in California (Brooks and Stensrud 2000; Palecki et al. 2005; Lamjiri et al. 2017), and tools such as NOAA Atlas 14 (https://hdsc.nws.noaa.gov/hdsc/pfds/ pfds_map_cont.html) provide precipitation intensities at various recurrence intervals at a point. This study fills an important information gap by presenting a climatological analysis of the spatial and temporal distribution of precipitation exceeding intensities pertinent to historic landsliding.

Our results support the refinement and development of landslide-triggering thresholds by demonstrating where and how frequently precipitation over various intensities occurs. For example, the northern Sierra Nevada province has some of the highest counts of OTPEs in the state for most thresholds; however, observed landslide incidence is low in the region (Figure 1). This information can help geologists weigh the impacts of observation bias, geology, and precipitation intensity in representing landslide activity in this region. For some stations in the Transverse Ranges, the number of storm events where multiple triggering thresholds are met (e.g., Figure 7b) is greater than the number of known widespread landslide events in this region. This provides confirmation that factors beyond exceedance of precipitation thresholds play a role in landslide susceptibility. For example, midwinter dry periods may reduce soil moisture such that a simple 
Earth Interactions - Volume 22 (2018) - Paper No. 14 • Page 21

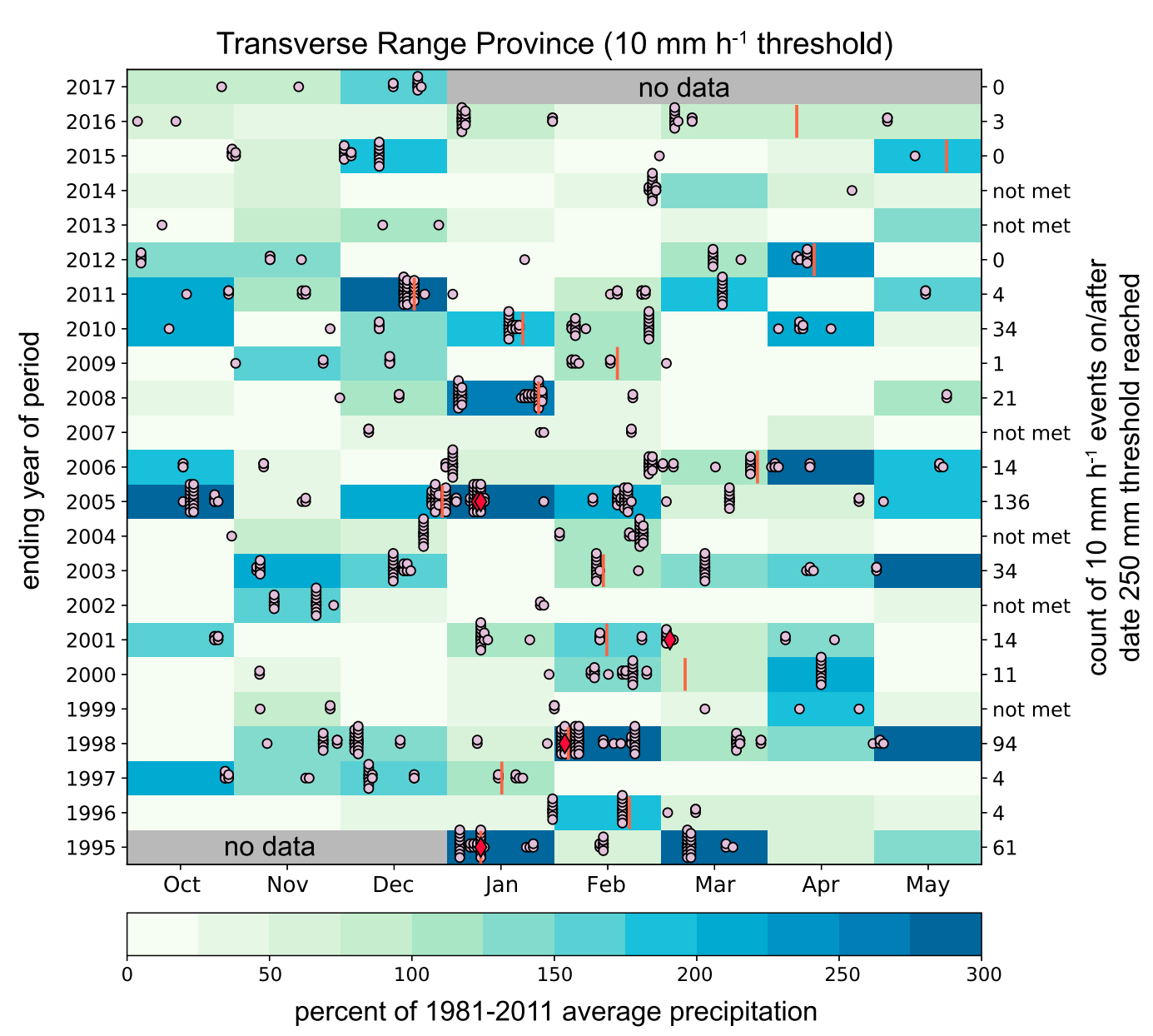

Figure 12. Monthly percent of average precipitation (colored squares), date on which $250-\mathrm{mm}$ antecedent precipitation threshold is achieved (pink bars), date and number of $T_{10}$ OTPEs (light pink circles; a maximum of 10 OTPEs for a date shown), and regional shallow landslide events (red diamonds) for the Transverse Ranges geomorphic province. Text on right side of each panel provides the number of OTPEs occurring after the $250-\mathrm{mm}$ threshold is reached in each season; "not met"' indicates the 250-mm threshold was not reached. References for shallow landslide events are provided in section 2.6. No OTPEs are included for Oct-Dec 1994, and neither OTPEs nor percent of average precipitation data are included for Jan-May 2017; OTPE analysis spans only calendar years 1995-2016. This figure was modeled after a figure in Biasutti et al. (2016).

seasonal antecedent rainfall total is not applicable. Alternatively, shallow landslides in excessively well-drained soils may have little dependence on antecedent rainfall. The existence of storms where multiple triggering thresholds are met multiple times highlights the need for accurate forecasting of these storms and hourly to subhourly precipitation intensity and duration, a capability that is currently emerging in operational numerical weather modeling. 
Earth Interactions - Volume 22 (2018) • Paper No. 14 • Page 22
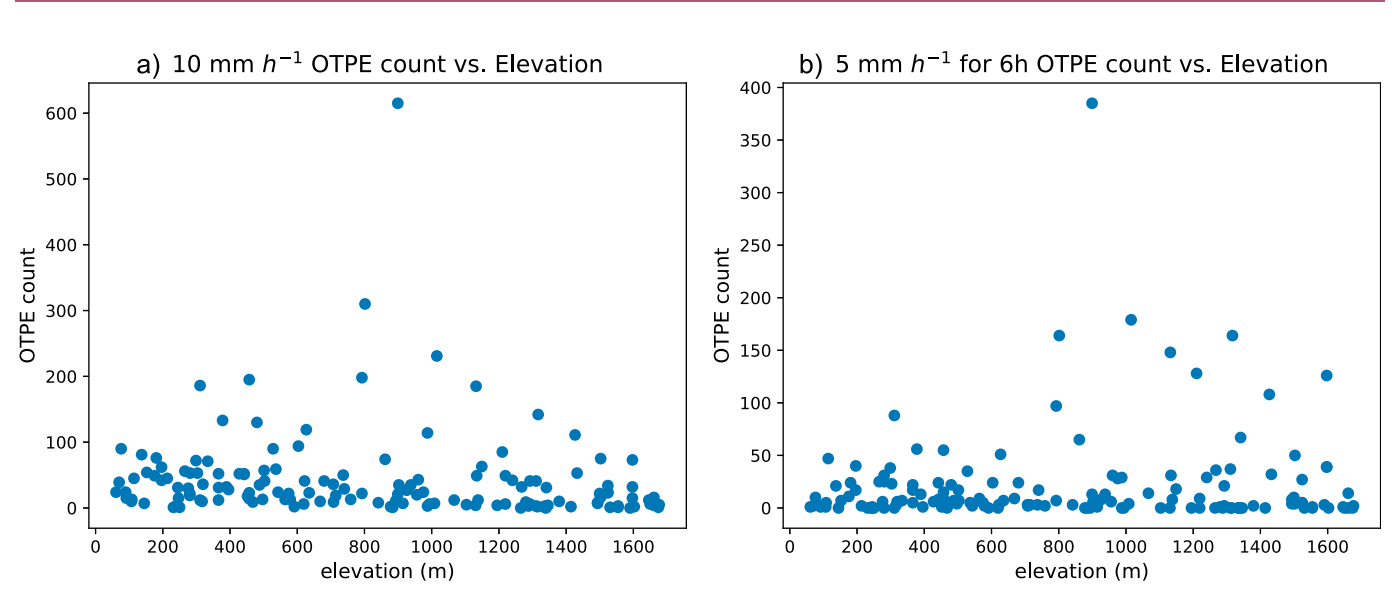

Figure 13. Number of overthreshold precipitation events compared with elevation for (a) $10 \mathrm{~mm} \mathrm{~h}^{-1}\left(T_{10}, r^{2}=0.01\right)$ and (b) $5 \mathrm{~mm} \mathrm{~h}^{-1}$ for $6 \mathrm{~h}\left(T_{6 \mathrm{~h}}, r^{2}=0.01\right)$ for 147 RAWS used in this study.

Permanent soil moisture sensors are limited in California, yet they are a necessary tool for forecasting landslide activity (e.g., Baum and Godt 2010). Our results elucidate where triggering rainfall is most likely to occur and, as a supplement to geological information, can inform where siting of new soil moisture sensors may provide the greatest benefit in landslide monitoring and warning systems. The precipitation intensity information generated in this study facilitates the development of a null shallow landslide map by indicating where high-intensity precipitation during the cool season is unlikely in California. Incorporating climatological precipitationintensity data into landslide hazard mapping algorithms can be used to move from susceptibility maps to potential maps, as suggested in Wills et al. (2011).

The relationship of ARs to OTPEs has implications for forecasting and situational awareness of potential landslide events. Integrated water vapor transport (IVT), one measure of AR conditions, has been shown to have better predictability than precipitation forecasts for a longer lead time (Lavers et al. 2016). A variety of tools exist at the Center for Western Weather and Water Extremes (http://cw3e. ucsd.edu/; Cordeira et al. 2017) for monitoring the forecasted and observed intensity and duration of AR conditions in California. People involved in research or monitoring of landslide hazards can utilize these tools to support their work.

Several limitations exist in this research. The period analyzed is relatively short, spanning only slightly more than two decades; thus, it is limited in how much climatological variability is represented. The RAWS precipitation data have limitations due to their instrumentation and other factors described in the appendix. The locations of RAWS used in this study do not represent all elevations and aspects, and there are an unequal number of stations per province. We utilize only one precipitation gauge network in this study; during the research period, it was the most spatially relevant data that were both accessible and usable. This limited the challenges of evaluating inhomogeneity between station networks. Future work could expand this study to include multiple networks and sufficient data for interpolation between points in complex terrain. 
Earth Interactions - Volume 22 (2018) • Paper No. 14 • Page 23

There is a limited number of thresholds available in the literature that describe landslide triggering in California, and most are developed for the Transverse Ranges or San Francisco Bay Area (Guzzetti et al. 2007; http://rainfallthresholds. irpi.cnr.it/). The geologic and hillslope processes in these areas are a small sample of a geologically diverse state. While all potential intensity-duration thresholds are not assessed in this work, we cover a range that is inclusive of minimum and maximum values in published literature. We do not suggest the thresholds provided should be applied across the state, but rather provide these results as a guide to where OTPEs at various thresholds occur such that the reader can relate them to known landslide activity or potential and other topics of interest dependent on high-intensity precipitation.

\section{Conclusions}

We assessed the spatial and temporal variability of precipitation events exceeding published estimates of rainfall intensities that triggered historic shallow landslides. We utilized quality-controlled data (see appendix) from Remote $\mathrm{Au}-$ tomated Weather Stations (RAWS) during the October-May season, when landslides are likely to occur. We found the following:

- Stations with exposure to southerly atmospheric flow in the Coast Ranges and Transverse Ranges experience high numbers of OTPEs.

- The northwestern Sierra Nevada also observes frequent OTPEs, likely related to the San Francisco Bay Area terrain gap (White et al. 2015).

- In the regions experiencing the highest OTPEs, approximately 60\%-90\% of OTPEs are associated with atmospheric rivers.

- Number of OTPEs varies greatly both within a season and interannually, though the greatest frequency of OTPEs tends to coincide with the climatological wettest month of the year at all thresholds.

- It is common for many OTPE events to occur within an individual storm event, especially at lower intensities $\left(T_{5}, T_{10}\right)$ or multihour thresholds.

Areas of frequent OTPEs generally match areas known to have the greatest landslide incidence or hazard (Figure 1; Brabb et al. 1999; Wills et al. 2017). Our results also highlight areas where OTPEs occur and landslide observations are lacking (i.e., the Sierra Nevada).

Shallow landslides that mobilize as debris flows threaten the lives and welfare of Californians and others living within and near steep terrain around the world. Climate model projections suggest an increase in the frequency and duration of dry periods in California. These periods may be punctuated by more extreme precipitation events (Polade et al. 2014; Cook et al. 2015; Dettinger 2016), which can reduce the likelihood of reaching season antecedent precipitation thresholds. However, short-duration precipitation extremes have already been observed to intensify over the observed record (e.g., Russo et al. 2013) and will likely intensify in a changing climate (Modrick and Georgakakos 2015; Prein et al. 2017), raising concern from the landslide-triggering standpoint. Our work provides information on the current spatial and temporal patterns of precipitation at a variety of intensities. This can serve as a baseline for considering future change and where intensification of extremes may pose the most significant threats. 
Earth Interactions - Volume 22 (2018) • Paper No. 14 • Page 24

Acknowledgments. The authors thank two anonymous reviewers for their helpful comments that improved the quality of this manuscript. We thank Scotty Strachan at University of Nevada, Reno, for useful insights to data quality control. This work was supported by the California Department of Water Resources, California Natural Resources Agency Contract 4600010378 and, in part, by the National Oceanic and Atmospheric Administration's Climate Program Office through Grant NA11OAR4310150 with the California Nevada Applications Program. Oakley and Hatchett were also supported in part by the National Aeronautics and Space Administration under Grants NNX10AN23H (Oakley) and NNX15AI02H (Hatchett) issued through the Nevada NASA Space Grant Consortium. C-2015 ASCAT data are produced by Remote Sensing Systems and sponsored by the NASA Ocean Vector Winds Science Team. Data are available at www.remss. com. All data used are accessible online from references provided.

\section{Appendix: Quality Control Methods for Remote Automated Weather Station (RAWS) Data}

This study utilizes data from the RAWS network (Zachariassen et al. 2003; Brown et al. 2011), operated by the National Interagency Fire Center (NIFC) and its partners. To utilize the RAWS dataset, we performed quality control on the RAWS precipitation data with a goal of optimization: developing a QC method that minimizes bad precipitation values and maximizes valid values. Our method explores several QC approaches and compares the results of each to a set of "known" values to quantify performance. Results of the best-performing QC method were used as the study dataset.

\section{A. 1. RAWS network selection}

The RAWS network was chosen for this analysis because its stations are situated in complex terrain: foothills and lower slopes of mountain ranges, where landslides most often occur. RAWS augment areas that typically have sparse data in the mountainous regions of the West and fill in a midelevation observation gap that is not covered by other networks like the Snowpack Telemetry (SNOTEL) network (high elevation) and the majority of mesonets that tend toward population centers or transportation corridors (Myrick and Horel 2008).

Several factors may contribute to erroneous precipitation records at RAWS:

1) Tipping-bucket gauges are not heated and, therefore, do not measure frozen precipitation well and are subject to freezing (Daly et al. 2008; Vose et al. 2014).

2) Frozen precipitation collects on gauges and melts when temperatures increase, registering erroneous hourly measurements; however, these values are typically smaller in magnitude than the thresholds pertinent to this study.

3) Local RAWS owners/operators may enter accumulated precipitation from a period of missing data as an hourly value, resulting in an erroneous hourly precipitation record (G. McCurdy 2017, personal communication).

4) Wire exposure/malfunction may cause one or a series of incorrect precipitation observations, as will transmission or data coding errors (G. McCurdy 2017, personal communication). 
Earth Interactions • Volume 22 (2018) • Paper No. 14 • Page 25

Data for 455 RAWS locations in California were obtained from the Western Regional Climate Center (http://raws.dri.edu). QC for the gauge operational limits had been applied prior to our acquisition of the data. The following QC methods work to remove issues associated with the errors described above.

\section{A.2. Development of a "truth" dataset to evaluate QC methods}

To quantify the performance of each QC attempt, a "truth" dataset was developed, with the term "truth" indicating that values had been examined through various means and documented as "valid" (should appear in the final QC dataset) or "bad" (should not appear in the final QC dataset).

The truth dataset consists of precipitation values $\geq 25 \mathrm{~mm} \mathrm{~h}^{-1}$. We focus on this subset of observations for several reasons:

1) In explorations of the data, values that clearly stood out as being erroneous (e.g., a single hour of precipitation in the cool season on a day when there was otherwise no precipitation) were generally $\geq 25 \mathrm{~mm} \mathrm{~h}^{-1}$. These errors were typically associated with error types 3 or 4 above.

2) When using radar imagery to validate precipitation, it is more feasible to validate the presence or lack of very high-intensity rainfall than moderate or light rainfall due to a stronger signal.

3) Values $\geq 25 \mathrm{~mm} \mathrm{~h}^{-1}$ are relevant to all landslide-triggering thresholds assessed.

The validity of precipitation values in the truth dataset was determined using archive radar imagery from the National Centers for Environmental Information (https://gis.ncdc.noaa.gov/maps/ncei/radar) and data from other fields (temperature, solar radiation, and relative humidity) from the RAWS in question, as well as neighboring stations both within and outside the RAWS network, obtained from WRCC (https://wrcc.dri.edu/). If these various resources indicated that it was likely that a particular value occurred, that value was considered valid. If the sources consulted suggested the value was unlikely (e.g., no radar returns on the specified date/time, other instruments on the station and surrounding stations show no precipitation, low relative humidity, or lack cloudiness) then the value is considered bad. There are inherent limitations in the development of the truth dataset, though it provides a qualitative means to evaluate QC methods, which offers a great benefit.

The resultant truth dataset consists of 62 valid and 62 bad values (total of 124 values) for the period 1995-2016. The results comparing each QC trial to the truth dataset are described in Table A1 and Figure A1.

\section{A.3. Quality control process}

The method used to QC RAWS precipitation data follows the framework of a four-level process for rain gauge quality control proposed by Kondragunta and Shrestha (2006) and applied by Kim et al. (2009) in reprocessing of Hydrometeorological Automated Data System (HADS) hourly precipitation data. 
Table A1. QC trials and their outcomes as compared to a truth dataset. The selected $Q C$ method is shown in bold. For column " $\pm 1 \mathrm{~h}$ ": if the observed precipitation value was $\geq 25 \mathrm{~mm} \mathrm{~h}^{-1}$, it requires precipitation an hour prior or following. This column indicates if this check was applied to the whole year, September-May only, or not at all. For column "buddy check": Compared stations against other stations within $0.5^{\circ} \times 0.5^{\circ}$ box to assess if they observed precipitation as well. This column indicates whether a buddy check was performed and whether for the whole year or November-April periods only. It also indicates whether a buddy needed to have a value simply $>0$ or a value that was $>10 \%$ of the value in question to validate. For column " \% valid excluded": when data resulting from a QC scheme were compared against 62 known valid values, this is the fraction that was excluded. For column "\% bad included": when the final data resulting from a QC scheme were compared against 62 known bad values, this is the fraction that was included in the final data.

\begin{tabular}{|c|c|c|c|c|c|c|c|c|}
\hline \multirow[b]{2}{*}{ QC round } & \multicolumn{2}{|c|}{ $\pm 1 \mathrm{~h}$} & \multicolumn{4}{|c|}{ Buddy check } & \multirow{2}{*}{$\begin{array}{l}\text { Percent valid } \\
\text { excluded }\end{array}$} & \multirow{2}{*}{$\begin{array}{l}\text { Percent bac } \\
\text { included }\end{array}$} \\
\hline & All year & Sep-May & All year & Nov-Apr & $>0$ & $>10 \%$ & & \\
\hline 1 & & & & & & & $0 \%$ & $98 \%$ \\
\hline 2 & $\mathrm{X}$ & & & $\mathrm{X}$ & $\mathrm{X}$ & & $8.1 \%$ & $30.7 \%$ \\
\hline 3 & $\mathrm{X}$ & & $\mathrm{X}$ & & $\mathrm{X}$ & & $14.5 \%$ & $24.2 \%$ \\
\hline 4 & $\mathrm{X}$ & & $\mathrm{X}$ & & & $\mathrm{X}$ & $19.4 \%$ & $14.5 \%$ \\
\hline 5 & $\mathrm{X}$ & & & $\mathrm{X}$ & & $\mathrm{X}$ & $8.1 \%$ & $24.2 \%$ \\
\hline 6 & & & $\mathrm{X}$ & & $\mathrm{X}$ & & $8.1 \%$ & $53.2 \%$ \\
\hline 7 & & & $\mathrm{X}$ & & & $\mathrm{X}$ & $14.5 \%$ & $30.7 \%$ \\
\hline 8 & & & & $\mathrm{X}$ & $\mathrm{X}$ & & $0 \%$ & $85.5 \%$ \\
\hline 9 & & $\mathbf{X}$ & $\mathbf{X}$ & & & $\mathbf{X}$ & $14.5 \%$ & $17.7 \%$ \\
\hline 10 & & $\mathrm{X}$ & $\mathrm{X}$ & & $X$ & & $8.1 \%$ & $29 \%$ \\
\hline 11 & & $\mathrm{X}$ & & $\begin{array}{c}\text { Sep-May } \\
\text { X }\end{array}$ & & $\mathrm{X}$ & $1.6 \%$ & $41.9 \%$ \\
\hline
\end{tabular}

\section{A.3.1. Level 1 QC}

Level 1 QC is performed on a single observation and includes transmission or coding errors or meaningless values like negative precipitation (Kondragunta and Shrestha 2006).

In this step, we calculate incremental values from the native accumulating values. If two consecutive data points are not consecutive hours, the incremental value is set as missing, and the check begins at the next value. This step also looks for station resets to 0 or negative accumulations, which are set to incremental values of missing for the hour in which they occurred.

\section{A.3.2. Level 2 QC}

Level 2 QC is performed on a single observation and checked against some boundaries for validity; it is referred to as a climatological range check by Kondragunta and Shrestha (2006).

At level $2 \mathrm{a}$, we first remove all values $>130 \mathrm{~mm} \mathrm{~h}^{-1}$. This is based on the greatest 1000-yr return intervals for hourly precipitation in California according to 


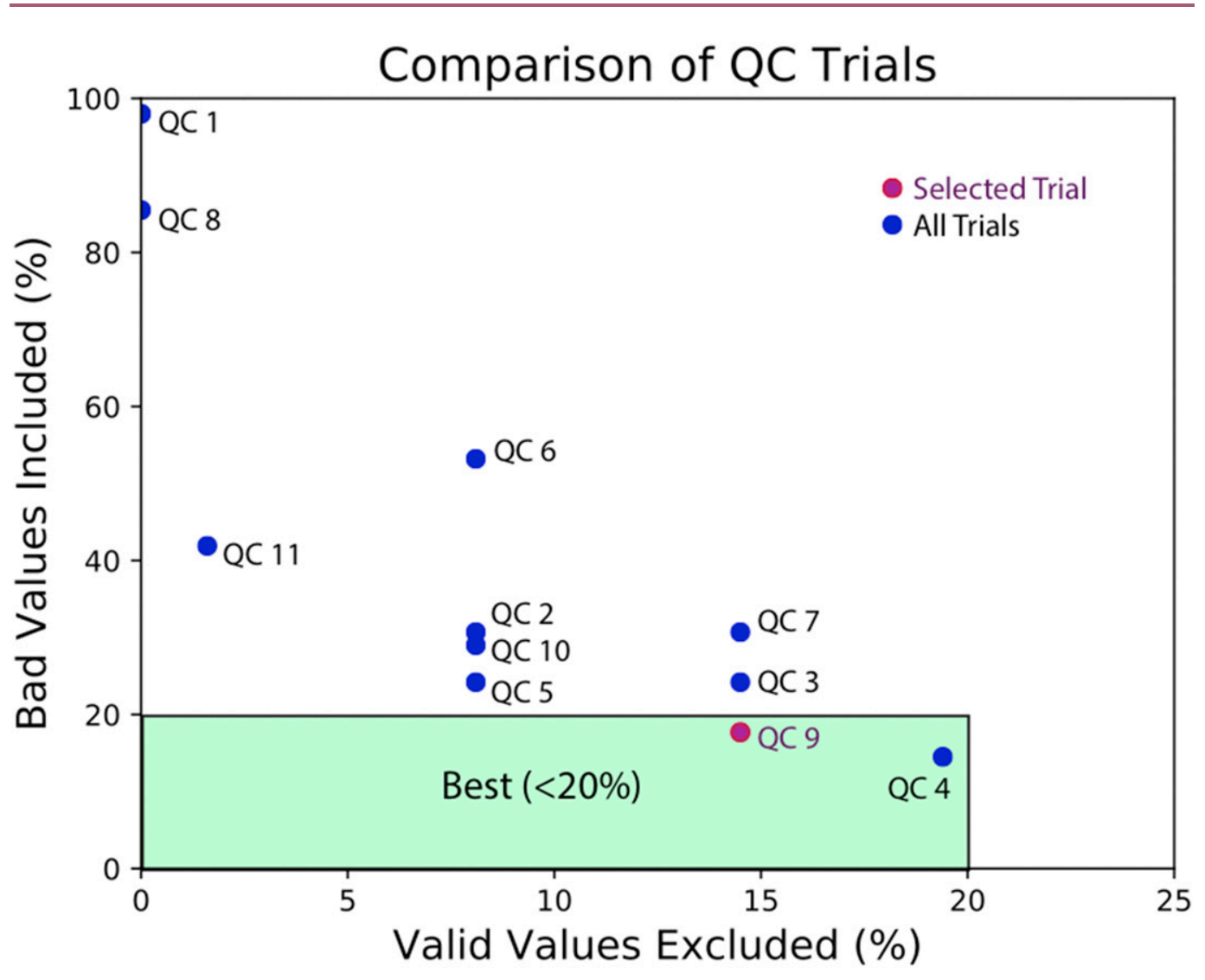

Figure A1. Comparison of $\mathrm{QC}$ trials and their performance, with respect to excluding bad values and including valid values from the truth dataset. The best-performing trials were rounds 4 and 9 . Round 9 was selected as the final $Q C$ method for its better performance at incorporating valid values in the known dataset.

the NOAA Atlas 14 (Perica et al. 2014) and exceeds all maximum hourly values at first-order California stations presented in Jennings (1963). This check helps address errors associated with challenges 3 and 4 given above.

As a secondary level 2 QC check, in level $2 \mathrm{~b}$, we tested removing cases where the incremental precipitation value was $\geq 25 \mathrm{~mm} \mathrm{~h}^{-1}$ and no precipitation was observed in the prior or following hour for the September-May season. This check was introduced to help remove erroneous isolated values of high precipitation, such as those introduced by error types 2 and 3 above. We tested this check all year versus September-May only (Table A1) and found the most favorable results using September-May only. We reason this check performs best during the cool season, as this is when synoptic-scale storms are most prevalent in California, and it is unlikely that a burst of rain confined to a single hour would occur in these storms. In contrast, high-intensity and very localized thunderstorms are possible in many areas of California in the summertime. This check - though not ideal, as there are valid meteorological events that violate this criteria—serves to remove many 
Earth Interactions - Volume 22 (2018) • Paper No. 14 • Page 28

invalid data points associated with error types 3 and 4 that proved difficult to remove by other means.

\section{A.3.3. Level 3 QC}

This level includes more advanced checks, including a spatial consistency check (buddy check) and a multisensor check (Kondragunta and Shrestha 2006).

At this level, we implement a "buddy check" to address errors from challenges 2 and 4 and, to a lesser extent, type 2 . All stations within a $0.5^{\circ}$ box around the station are examined as "buddies." This resulted in an average of 13 buddies per station. The buddy check was conducted on all values $\geq 5 \mathrm{~mm} \mathrm{~h}^{-1}$, the minimum hourly value of interest to this project. We tested variants of applying the buddy check to the various parts of the season and also whether better results were achieved looking for a buddy with $>0$ precipitation or a buddy with $>10 \%$ of the observed value at the station in question (Table A1). The best-performing option was performing a buddy check all year, where a buddy must have at least $10 \%$ of what was observed at the station in question.

To validate a station's observation, at least one buddy had to meet the precipitation value criteria within $\pm 2 \mathrm{~h}$ of the observed time. For a value to be considered bad, a station had to have at least three buddies reporting $<10 \%$ when the station in question reported $\geq 5 \mathrm{~mm} \mathrm{~h}^{-1}$. Therefore, a station with fewer than three buddies reporting at that time would not be subject to this check. Sensitivity tests revealed that requiring only one or two buddies was too lax (in some cases, a nearby station was reporting erroneously as well), and requiring more than three buddies left many values/stations not evaluated due to the lack of nearby stations. Of the 455 stations examined, only 19 had fewer than three buddies.

We found this check very beneficial for removing erroneous cool season values, but due to the isolated nature of summertime thunderstorms, the buddy check removed some valid values in the summertime. However, we do not utilize the summer season in the final analysis.

\section{A.3.4. Level 4 QC}

Corrections at this level are based on human expert judgment, such as knowledge of the gauge history or ancillary information on a particular weather event (Kondragunta and Shrestha 2006).

At level 4, we have now performed QC on the full year for all stations. For the purpose of investigating precipitation intensities that may trigger shallow landslides, we create a subset of stations at this QC level.

We maintain all stations that have $>80 \%$ of data for the October-May period across the 22-yr period 1995-2016, resulting in 166 stations across California. Setting the threshold of missing data at $80 \%-85 \%$ is common practice in climatological analyses (Daly et al. 2008; Abatzoglou 2013; Perica et al. 2014). We also remove all stations at an elevation of $\leq 1700 \mathrm{~m}$. This is intended to remove stations that are typically situated above the approximate climatological median snow level in the Sierra. This reduces the final station count to 147. 
Earth Interactions - Volume 22 (2018) • Paper No. 14 • Page 29

Last, all values where the temperature is $\leq 0^{\circ} \mathrm{C}$ are removed to account for RAWS data challenge 1 stated in section A.1. above. There is uncertainty and variability around the temperature at which frozen precipitation occurs (e.g., Lundquist et al. 2008), and we cannot ensure the station temperature sensor is functioning correctly. However, we present this check as a rough approximation to reduce erroneous values associated with frozen precipitation.

The best-performing QC method (that which maximized exclusion of bad values while minimizing exclusion of valid values) was round 9 (14.5\% valid excluded, $17.7 \%$ bad included; Table A1 and Figure A1). While the amount of error is not ideal, it shows a marked improvement from round 1, where nearly all of the bad values were accepted. For the October-May period only, when resultant data were compared to the truth dataset values for that date range, no valid values were excluded (0/30), and $20 \%$ of bad values were included (8/40). Following the evaluation process, the truth values were inserted into or removed from the final dataset.

\section{A.4. Summary of selected QC approach}

The selected QC process (round 9) had the following checks applied, as shown in Table A1:

- Remove station resets, negative accumulations, and transmission errors.

- Remove values $>130 \mathrm{~mm} \mathrm{~h}^{-1}$.

- For September-May, remove all cases where $\geq 25 \mathrm{~mm} \mathrm{~h}^{-1}$ and no precipitation occurs in preceding or following hour.

- Throughout the year, perform buddy check and require at least one buddy to have $>10 \%$ of precipitation value in question.

- Retain stations with $>80 \%$ of October-May data, remove stations with elevation $>1700 \mathrm{~m}$, and remove precipitation when temperature $<0^{\circ} \mathrm{C}$.

\section{A.5. Discussion and limitations}

We present an approach to QC RAWS precipitation data, using a set of validated extreme $\left(\geq 25 \mathrm{~mm} \mathrm{~h}^{-1}\right)$ observations as a "known" dataset for comparison. This approach, like any QC approach, results in some subset of true precipitation at a location and has error associated with it. There are several limitations to this approach to be considered; however, we find the resulting analysis to capture the spatial and temporal patterns of precipitation exceeding various thresholds that we would expect from previous literature. The limitations and our rationale for accepting them are as follows:

1) RAWS do not have wind shields and are typically located in exposed areas. In this study, we do not account for gauge undercatch due to wind (Duchon and Biddle 2010) or due to lack of a shield (Duchon and Essenberg 2001). Winds over $5-6 \mathrm{~m} \mathrm{~s}^{-1}$ can produce undercatch on the order of $6 \%$, and correcting for these errors can be very problematic (Duchon and Biddle 2010). Undercatch associated with unshielded tipping-bucket gauges was $4 \%$ relative to a tipping-bucket pit gauge (Duchon and Essenberg 2001). 
Earth Interactions - Volume 22 (2018) • Paper No. 14 • Page 30

This study focuses on frequency of overthreshold precipitation events rather than precise magnitude of the events. This may cause frequency of events to be biased low.

2) RAWS are unheated, and any snow that collects on the gauge will melt and run through the gauge when temperatures warm. While it is unlikely that the melt-off will exceed the precipitation thresholds evaluated in this study, it may be possible and can potentially introduce an invalid value into the dataset in areas that experience snowfall. Removal of stations $>1700 \mathrm{~m}$ and the buddy check help to reduce these instances but cannot control all of them.

3) The known dataset consists of a small sample population within the data. The samples chosen may influence the outcome of proportions of valid excluded and bad included and, thus, the chosen QC method. It was not feasible to manually check all values in the dataset, so we had to accept this limitation.

4) There are hourly precipitation datasets available for California beyond the RAWS. We chose to focus research efforts on QC and implementation of one network (RAWS) that had stations in the most favorable locations. Future work could incorporate more datasets to both validate RAWS observations and increase spatial density of precipitation data.

5) We do not recommend use of this dataset for the evaluation of climatological precipitation. QC is applied with a focus on verifying extremes, and, with the many errors removed in this dataset as well as missing values, we do not believe it accurately represents precipitation over climatological periods (daily and monthly summaries) and is best utilized for event-based examinations, particularly hourly extremes.

6) This QC method does not remove errors in the warm season (June-August) well and, thus, may not be suitable for analysis during this period. As described above, it was extremely challenging to remove temporally and spatially isolated erroneous precipitation events while preserving similarly isolated valid events.

\section{References}

Abatzoglou, J. T., 2013: Development of gridded surface meteorological data for ecological applications and modelling. Int. J. Climatol., 33, 121-131, https://doi.org/10.1002/joc.3413.

— 2016: Contribution of cutoff lows to precipitation across the United States. J. Appl. Meteor. Climatol., 55, 893-899, https://doi.org/10.1175/JAMC-D-15-0255.1.

Baum, R. L., and J. W. Godt, 2010: Early warning of rainfall-induced shallow landslides and debris flows in the USA. Landslides, 7, 259-272, https://doi.org/10.1007/s10346-009-0177-0.

,-- , and W. Z. Savage, 2010: Estimating the timing and location of shallow rainfall-induced landslides using a model for transient, unsaturated infiltration. J. Geophys. Res., 115, F03013, https://doi.org/10.1029/2009JF001321.

Bedrossian, T. L., 1996: 1995 storm events: An overview of the Department of Conservation, Division of Mines and Geology's emergency landslide response. Calif. Geol., 49 (5), 111-119.

Biasutti, M., R. Seager, and D. B. Kirschbaum, 2016: Landslides in West Coast metropolitan areas: The role of extreme weather events. Wea. Climate Extremes, 14, 67-79, https://doi.org/ 10.1016/j.wace.2016.11.004.

Bogaard, T., and R. Greco, 2018: Invited perspectives: Hydrological perspectives on precipitation intensity-duration thresholds for landslide initiation: Proposing hydro-meteorological 
Earth Interactions V Volume 22 (2018) • Paper No. 14 • Page 31

thresholds. Nat. Hazards Earth Syst. Sci., 18, 31-39, https://doi.org/10.5194/nhess-18-312018.

Brabb, E. E., J. P. Colgan, and T. C. Best, 1999: Map showing inventory and regional susceptibility for Holocene debris flows, and related fast-moving landslides in the conterminous United States. U. S. Geological Survey Miscellaneous Field Studies Map MF- 2329, https://pubs.er. usgs.gov/publication/mf2329.

Brooks, H. E., and D. J. Stensrud, 2000: Climatology of heavy rain events in the United States from hourly precipitation observations. Mon. Wea. Rev., 128, 1194-1201, https://doi.org/10.1175/ 1520-0493(2000)128<1194:COHREI >2.0.CO;2.

Brown, T. J., J. D. Horel, G. D. McCurdy, and M. G. Fearon, 2011: What is the appropriate RAWS network? Center for Climate, Ecosystem, and Fire Applications Rep. 11-01, 97 pp., https:// cefa.dri.edu/Publications/RAWS\%20Network\%20Analysis\%20final\%20report.pdf.

Caine, N., 1980: The rainfall intensity: Duration control of shallow landslides and debris flows. Geogr. Ann., 62A, 23-27, https://doi.org/10.2307/520449.

Campbell, R. H., 1975: Soil slips, debris flows, and rainstorms in the Santa Monica Mountains and vicinity, southern California. U.S. Geological Survey Rep. 851, 51 pp., https://pubs.usgs.gov/ pp/0851/report.pdf.

Cannon, S. H., and S. D. Ellen, 1985: Rainfall conditions for abundant debris avalanches, San Francisco Bay region, California. Calif. Geol., 38 (12), 267-272.

— and - 1988: Rainfall that resulted in abundant debris flow activity during the storm. Landslides, floods, and marine effects of the storm of January 3-5, 1982, in the San Francisco Bay region, California, S. D. Ellen and G. F. Wieczorek, Eds., U.S. Geological Survey Professional Paper 1434, 27-33.

Casadei, M., W. E. Dietrich, and N. L. Miller, 2003: Testing a model for predicting the timing and location of shallow landslide initiation in soil-mantled landscapes. Earth Surf. Processes Landforms, 28, 925-950, https://doi.org/10.1002/esp.470.

CGS, 2002: California geomorphic provinces. California Geological Survey Note 36, 4 pp., http:// www.conservation.ca.gov/cgs/Documents/Note_36.pdf.

Cook, B. I., T. R. Ault, and J. E. Smerdon, 2015: Unprecedented 21st century drought risk in the American Southwest and central Plains. Sci. Adv., 1, e1400082, https://doi.org/10.1126/ sciadv. 1400082.

Cordeira, J. M., F. M. Ralph, A. Martin, N. Gaggini, J. R. Spackman, P. J. Neiman, J. J. Rutz, and R. Pierce, 2017: Forecasting atmospheric rivers during CalWater 2015. Bull. Amer. Meteor. Soc., 98, 449-459, https://doi.org/10.1175/BAMS-D-15-00245.1.

Daly, C., M. Halbleib, J. I. Smith, W. P. Gibson, M. K. Doggett, G. H. Taylor, J. Curtis, and P. P. Pasteris, 2008: Physiographically sensitive mapping of climatological temperature and precipitation across the conterminous United States. Int. J. Climatol., 28, 2031-2064, https://doi. org/10.1002/joc.1688.

Dettinger, M. D., 2016: Historical and future relations between large storms and droughts in California. San Francisco Estuary Watershed Sci., 14 (2), 1-21, https://doi.org/10.15447/ sfews.2016v14iss2art2.

Duchon, C. E., and G. R. Essenberg, 2001: Comparative rainfall observations from pit and aboveground rain gauges with and without wind shields. Water Resour. Res., 37, 3253-3263, https://doi.org/10.1029/2001WR000541.

— and C. J. Biddle, 2010: Undercatch of tipping-bucket gauges in high rain rate events. $A d v$. Geosci., 25, 11-15, https://doi.org/10.5194/adgeo-25-11-2010.

Godt, J. W., R. L. Baum, and A. F. Chleborad, 2006: Rainfall characteristics for shallow landsliding in Seattle, Washington, USA. Earth Surf. Processes Landforms, 31, 97-110, https://doi.org/ 10.1002/esp.1237.

Guzzetti, F., S. Peruccacci, M. Rossi, and C. P. Stark, 2007: Rainfall thresholds for the initiation of landslides in central and southern Europe. Meteor. Atmos. Phys., 98, 239-267, https://doi.org/ 10.1007/s00703-007-0262-7. 
Earth Interactions - Volume 22 (2018) - Paper No. 14 • Page 32

$-, \ldots, \ldots$, and _ $—$ 2008: The rainfall intensity-duration control of shallow landslides and debris flows: An update. Landslides, 5, 3-17, https://doi.org/10.1007/s10346-007-0112-1.

Hansch, S., L. Locklin, C. Willis, and L. Ewing, 1998: Coastal impacts of the 1997-98 El Niño and predictions for La Niña. California Coastal Commission Rep. Tu-11, 14 pp., https:// documents.coastal.ca.gov/reports/1998/9/T11-9-1998.pdf.

Hatchett, B. J., B. Daudert, C. B. Garner, N. S. Oakley, A. E. Putnam, and A. B. White, 2017: Winter snow level rise in the northern Sierra Nevada from 2008 to 2017. Water, 9, 899, https:// doi.org/10.3390/w9110899.

Hecht, C. W., and J. M. Cordeira, 2017: Characterizing the influence of atmospheric river orientation and intensity on precipitation distributions over north coastal California. Geophys. Res. Lett., 44, 9048-9058, https://doi.org/10.1002/2017GL074179.

Hughes, M., A. Hall, and R. G. Fovell, 2009: Blocking in areas of complex topography, and its influence on rainfall distribution. J. Atmos. Sci., 66, 508-518, https://doi.org/10.1175/ 2008JAS2689.1.

Irvine, P. J., 1996: Debris flows resulting from January 1995 rainstorms. Calif. Geol., 49 (5), 129-134.

Iverson, R. M., 2000: Landslide triggering by rain infiltration. Water Resour. Res., 36, 1897-1910, https://doi.org/10.1029/2000WR900090.

Jakob, M., and O. Hungr, 2005: Debris-Flow Hazards and Related Phenomena. Springer, 739 pp.

Jennings, A. H., 1963: Maximum recorded United States point rainfall for 5 minutes to 24 hours at 296 first-order stations. U.S. Department of Commerce Tech. Paper 2., 60 pp., http://www. nws.noaa.gov/oh/hdsc/Technical_papers/TP2.pdf.

Johnson, K. A., and N. Sitar, 1990: Hydrologic conditions leading to debris-flow initiation. Can. Geotech. J., 27, 789-801, https://doi.org/10.1139/t90-092.

Kalnay, E., and Coauthors, 1996: The NCEP/NCAR 40-Year Reanalysis Project. Bull. Amer. Meteor. Soc., 77, 437-472, https://doi.org/10.1175/1520-0477(1996)077<0437: TNYRP $>2.0 . \mathrm{CO} ; 2$.

Kim, D., B. Nelson, and D. J. Seo, 2009: Characteristics of reprocessed Hydrometeorological Automated Data System (HADS) hourly precipitation data. Wea. Forecasting, 24, 12871296, https://doi.org/10.1175/2009WAF2222227.1.

Kondragunta, C. R., and K. Shrestha, 2006: Automated real-time operational rain gauge quality control tools in NWS hydrologic operations. 20th Conf. on Hydrology, Atlanta, GA, Amer. Meteor. Soc., P2.4, https://ams.confex.com/ams/Annual2006/techprogram/paper_102834.htm.

Lamjiri, M. A., M. D. Dettinger, F. M. Ralph, and B. Guan, 2017: Hourly storm characteristics along the U.S. West Coast: Role of atmospheric rivers in extreme precipitation. Geophys. Res. Lett., 44, 7020-7028, https://doi.org/10.1002/2017GL074193.

Larsen, M. C., and A. Simon, 1993: A rainfall intensity-duration threshold for landslides in a humid-tropical environment, Puerto Rico. Geogr. Ann., 75A, 13-23, https://doi.org/10.1080/ 04353676.1993.11880379.

Lavers, D. A., D. E. Waliser, F. M. Ralph, and M. D. Dettinger, 2016: Predictability of horizontal water vapor transport relative to precipitation: Enhancing situational awareness for forecasting western U.S. extreme precipitation and flooding. Geophys. Res. Lett., 43, 2275-2282, https://doi.org/10.1002/2016GL067765.

Lin, Y. L., S. Chiao, T. A. Wang, M. L. Kaplan, and R. P. Weglarz, 2001: Some common ingredients for heavy orographic rainfall. Wea. Forecasting, 16, 633-660, https://doi.org/10.1175/ 1520-0434(2001)016<0633:SCIFHO > 2.0.CO;2.

Lundquist, J. D., P. J. Neiman, B. Martner, A. B. White, D. J. Gottas, and F. M. Ralph, 2008: Rain versus snow in the Sierra Nevada, California: Comparing Doppler profiling radar and surface observations of melting level. J. Hydrometeor, 9, 194-211, https://doi.org/10.1175/ 2007JHM853.1.

— J. R. Minder, P. J. Neiman, and E. Sukovich, 2010: Relationships between barrier jet heights, orographic precipitation gradients, and streamflow in the northern Sierra Nevada. J. Hydrometeor., 11, 1141-1156, https://doi.org/10.1175/2010JHM1264.1. 


\section{Earth Interactions - Volume 22 (2018) - Paper No. 14 • Page 33}

Modrick, T. M., and K. P. Georgakakos, 2015: The character and causes of flash flood occurrence changes in mountainous small basins of Southern California under projected climatic change. J. Hydrol.: Reg. Stud., 3, 312-336, https://doi.org/10.1016/j.ejrh.2015.02.003.

Morton, D. M., R. M. Alvarez, and R. H. Campbell, 2003: Preliminary soil-slip susceptibility maps, southwestern California. U.S. Geological Survey Open-File Rep. 03-17, 14 pp., https://pubs. usgs.gov/of/2003/0017/.

Myrick, D. T., and J. D. Horel, 2008: Sensitivity of surface analyses over the western United States to RAWS observations. Wea. Forecasting, 23, 145-158, https://doi.org/10.1175/ 2007WAF2006074.1.

Neiman, P. J., F. M. Ralph, A. B. White, D. E. Kingsmill, and P. O. G. Persson, 2002: The statistical relationship between upslope flow and rainfall in California's coastal mountains: Observations during CALJET. Mon. Wea. Rev., 130, 1468-1492, https://doi.org/10.1175/ 1520-0493(2002)130<1468:TSRBUF $>2.0$. CO;2.

$\longrightarrow,-$, P. O. G. Persson, A. B. White, D. P. Jorgensen, and D. E. Kingsmill, 2004: Modification of fronts and precipitation by coastal blocking during an intense landfalling winter storm in Southern California: Observations during CALJET. Mon. Wea. Rev., 132, 242-273, https:// doi.org/10.1175/1520-0493(2004)132<0242:MOFAPB > 2.0.CO;2.

NRC, 2004: Partnerships for Reducing Landslide Risk: Assessment of the National Landslide Hazards Mitigation Strategy. National Academies Press, 143 pp.

Oakley, N. S., J. T. Lancaster, M. L. Kaplan, and F. M. Ralph, 2017: Synoptic conditions associated with cool season post-fire debris flows in the Transverse Ranges of Southern California. Nat. Hazards, 88, 327-354, https://doi.org/10.1007/s11069-017-2867-6.

Palecki, M. A., J. R. Angel, and S. E. Hollinger, 2005: Storm precipitation in the United States. Part I: Meteorological characteristics. J. Appl. Meteor., 44, 933-946, https://doi.org/10.1175/JAM2243.1.

Perica, S., and Coauthors, 2014: Precipitation-Frequency Atlas of the United States. NOAA Atlas 14, Vol. 6, version 2.3: California, 233 pp., http://www.nws.noaa.gov/oh/hdsc/PF_documents/ Atlas14_Volume6.pdf.

Polade, S. D., D. W. Pierce, D. R. Cayan, A. Gershunov, and M. D. Dettinger, 2014: The key role of dry days in changing regional climate and precipitation regimes. Sci. Rep., 4, 4364, https:// doi.org/10.1038/srep04364.

Prein, A. F., R. M. Rasmussen, K. Ikeda, C. Liu, M. P. Clark, and G. J. Holland, 2017: The future intensification of hourly precipitation extremes. Nat. Climate Change, 7, 48-52, https://doi. org/10.1038/nclimate3168.

Ralph, F. M., and M. D. Dettinger, 2012: Historical and national perspectives on extreme West Coast precipitation associated with atmospheric rivers during December 2010. Bull. Amer. Meteor. Soc., 93, 783-790, https://doi.org/10.1175/BAMS-D-11-00188.1.

— , P. J. Neiman, D. E. Kingsmill, P. O. Persson, A. B. White, E. T. Strem, E. D. Andrews, and R. C. Antweiler, 2003: The impact of a prominent rain shadow on flooding in California's Santa Cruz Mountains: A CALJET case study and sensitivity to the ENSO cycle. J. Hydrometeor, 4, 1243-1264, https://doi.org/10.1175/1525-7541(2003)004<1243:TIOAPR > 2.0.CO;2.

— - — and R. Rotunno, 2005: Dropsonde observations in low-level jets over the northeastern Pacific Ocean from CALJET-1998 and PACJET-2001: Mean vertical-profile and atmospheric-river characteristics. Mon. Wea. Rev., 133, 889-910, https://doi.org/10.1175/ MWR2896.1.

— - - G. A. Wick, S. I. Gutman, M. D. Dettinger, D. R. Cayan, and A. B. White, 2006: Flooding on California's Russian River: Role of atmospheric rivers. Geophys. Res. Lett., 33, L13801, https://doi.org/10.1029/2006GL026689.

Reid, M. E., 1997: Slope instability caused by small variations in hydraulic conductivity. J. Geotech. Geoenviron. Eng., 123, 717-725, https://doi.org/10.1061/(ASCE)1090-0241(1997)123:8(717).

Ricciardulli, L., and F. J. Wentz, 2016: Remote Sensing Systems ASCAT C-2015 daily ocean vector winds on 0.25 deg grid, version 02.1. Remote Sensing Systems, accessed 15 July 2017, www. remss.com/missions/ascat. 
Earth Interactions - Volume 22 (2018) • Paper No. 14 • Page 34

Russo, T. A., A. T. Fisher, and D. M. Winslow, 2013: Regional and local increases in storm intensity in the San Francisco Bay area, USA, between 1890 and 2010. J. Geophys. Res. Atmos., 118, 3392-3401, https://doi.org/10.1002/jgrd.50225.

Rutz, J. J., W. J. Steenburgh, and F. M. Ralph, 2014: Climatological characteristics of atmospheric rivers and their inland penetration over the western United States. Mon. Wea. Rev., 142, 905921, https://doi.org/10.1175/MWR-D-13-00168.1.

,-- , and $\longrightarrow, 2015$ : The inland penetration of atmospheric rivers over western North America: A Lagrangian analysis. Mon. Wea. Rev., 143, 1924-1944, https://doi.org/10.1175/ MWR-D-14-00288.1.

Santi, P. M., K. Hewitt, D. F. VanDine, and E. Barillas Cruz, 2011: Debris-flow impact, vulnerability, and response. Nat. Hazards, 56, 371-402, https://doi.org/10.1007/ s11069-010-9576-8.

Stock, J. D., and D. Bellugi, 2011: An empirical method to forecast the effect of storm intensity on shallow landslide abundance. Fifth Int. Conf. on Debris-Flow Hazards Mitigation: Mechanics, Prediction and Assessment, Padua, Italy, Casa Editrice Universita La Sapienza, 1013-1022, https://doi.org/10.4408/IJEGE.2011-03.B-110.

Vose, R. S., and Coauthors, 2014: Improved historical temperature and precipitation time series for U.S. climate divisions. J. Appl. Meteor. Climatol., 53, 1232-1251, https://doi.org/10.1175/ JAMC-D-13-0248.1.

White, A. B., P. J. Neiman, J. M. Creamean, T. Coleman, F. M. Ralph, and K. A. Prather, 2015: The impacts of California's San Francisco Bay Area gap on precipitation observed in the Sierra Nevada during HMT and CalWater. J. Hydrometeor., 16, 1048-1069, https://doi.org/10.1175/ JHM-D-14-0160.1.

Wieczorek, G. F., 1987: Effect of rainfall intensity and duration on debris flows in central Santa Cruz Mountains, California. Rev. Eng. Geol., 7, 93-104, https://doi.org/10.1130/REG7-p93.

—, 2002: Catastrophic rockfalls and rockslides in the Sierra Nevada, USA. Rev. Eng. Geol., 15, 165-190, https://doi.org/10.1130/REG15-p165.

— ifornia, in storms between 1975 and 1983. Landslides, floods, and marine effects of the storm of January 3-5, 1982, in the San Francisco Bay region, California, S. D. Ellen and G. F. Wieczorek, Eds., U.S. Geological Survey Professional Paper 1434, 27-33.

Wills, C. J., F. G. Perez, and C. I. Gutierrez, 2011: Susceptibility to deep-seated landslides in California. California Geological Survey Map Sheet 58, 1 pp., http://www.conservation.ca. gov/cgs/information/publications/ms/Documents/MS58.pdf.

—, N. E. Roth, T. P. McCrink, and W. R. Short, 2017: The California landslide inventory database. Proc. Third North American Symp. on Landslides, Association of Environmental and Engineering Geologists, Roanoke, VA, 666-674.

Wilson, R. C., 1997a: Operation of a landslide warning system during the California storm sequence of January and February 1993. Rev. Eng. Geol., 11, 61-70, https://doi.org/10.1130/ REG11-p61.

, 1997b: Broad-scale climatic influences on rainfall thresholds for debris flows: Adapting thresholds for Northern California to Southern California. Rev. Eng. Geol., 11, 71-80, https:// doi.org/10.1130/REG11-p71.

__ and G. F. Wieczorek, 1995: Rainfall thresholds for the initiation of debris flows at La Honda, California. Environ. Eng. Geosci., 1, 11-27, https://doi.org/10.2113/ gseegeosci.I.1.11.

— tivity, San Francisco Bay Region, California. U.S. Department of the Interior, U.S. Geological Survey Open-File Rep. 97-745-F, 20 pp., https://pubs.usgs.gov/of/1997/of97-745/ sfbr-rt-dbdesc.pdf.

WRCC, 2017: Cooperative climatological data summaries. Western Regional Climate Center, accessed 6 March 2017, https://wrcc.dri.edu/Climate/west_coop_summaries.php. 
Earth Interactions - Volume 22 (2018) • Paper No. 14 • Page 35

Young, A. M., K. T. Skelly, and J. M. Cordeira, 2017: High-impact hydrologic events and atmospheric rivers in California: An investigation using the NCEI Storm Events Database. Geophys. Res. Lett., 44, 3393-3401, https://doi.org/10.1002/2017GL073077.

Zachariassen, J., K. F. Zeller, N. Nikolov, and T. McClelland, 2003: A review of the Forest Service Remote Automated Weather Station (RAWS) network. USDA Tech. Rep. RMRS-GTR-119, 153 pp., https://www.fs.fed.us/rm/pubs/rmrs_gtr119.

Earth Interactions is published jointly by the American Meteorological Society, the American Geophysical Union, and the Association of American Geographers. For information regarding reuse of this content and general copyright information, consult the AMS Copyright Policy (www.ametsoc.org/PUBSReuseLicenses). 